\title{
كارواذ عهلى قادر
}

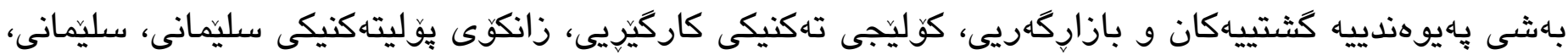
هـاريمى كوردستان، عيراق. ئيمهيل: karwan.ali@spu.edu.iq

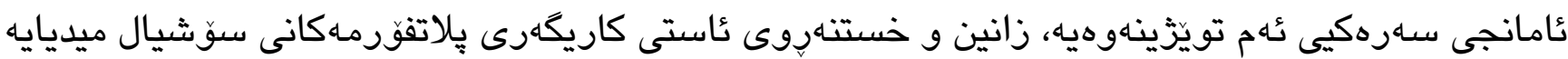

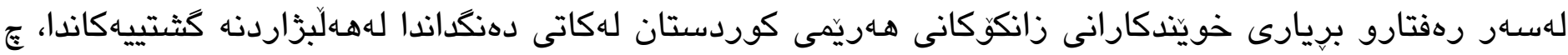
بو بهشداريان لهدهنكداندا يان بو دهنكدان بهكانديديك يان ليستيكى دياريكراوو زانينى ئاستى بهشدارييكردنيان و

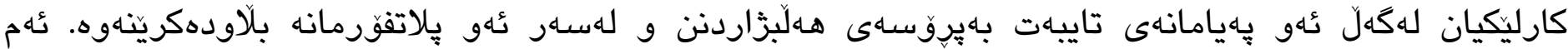
تويَّينهوهيه لهجوارجيّوهو فؤرمى تويَّينهوهى كوميونيكهيشنى سياسياهو بو كوكردنهوهى داتا بشتى بهستووه

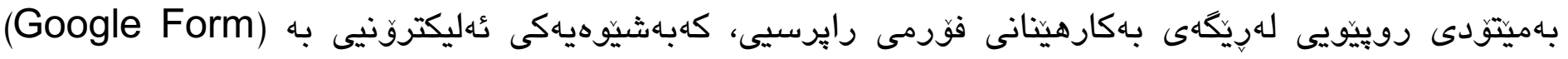

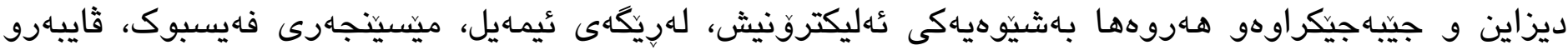
هـهروها واتسئهيهوه نيّردراوه بو مشتهيهك لهبهشداربوان كه خوينّكارانى زانكوكانى هـاريّمى كوردستانن و

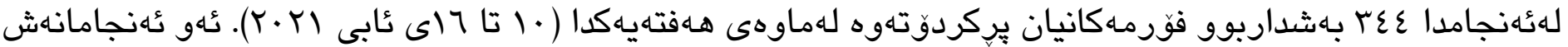

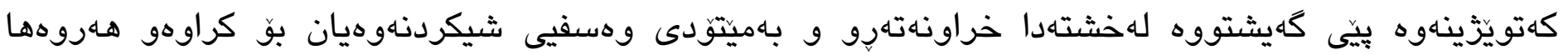

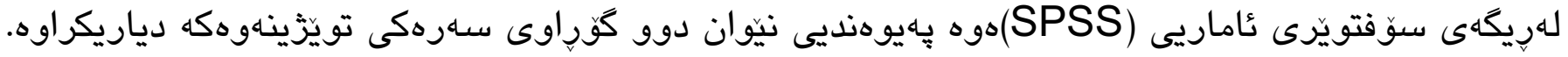

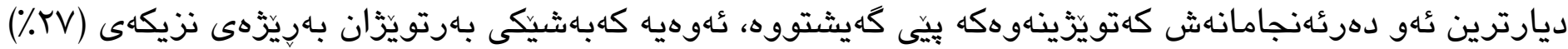

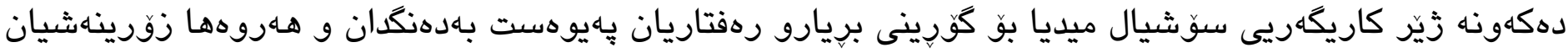
بهريّزهى نزيكهى (00\%) به بهداربوان متمانهيان بهو بهليّن و كفتانه نييه كه كانديدو لايهنه بهشداربووهكانى

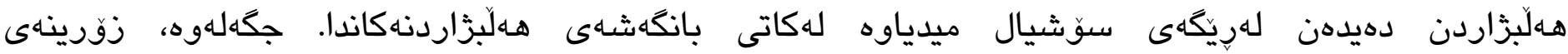

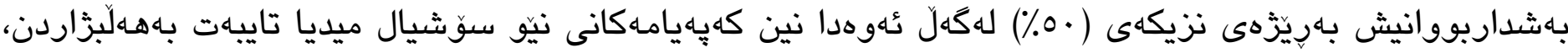
وايان ليّكات هـهتبكهن ئهو هـلّبزاردنانه كَّرِانكاريى لهزيانيان دهكات بهرهو باشتر.

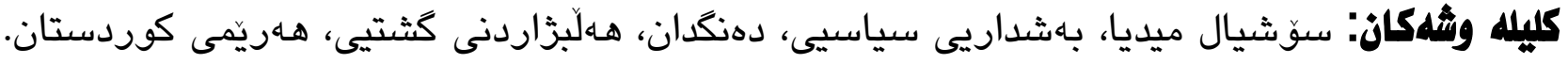




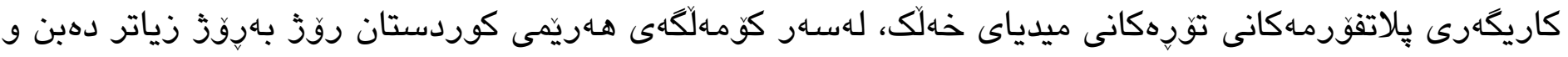

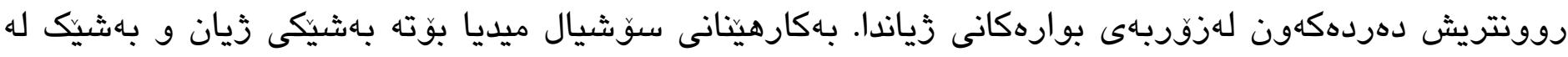

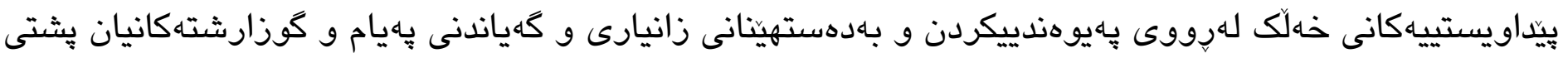

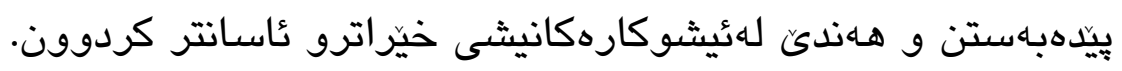

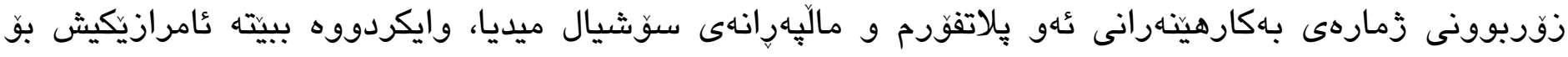

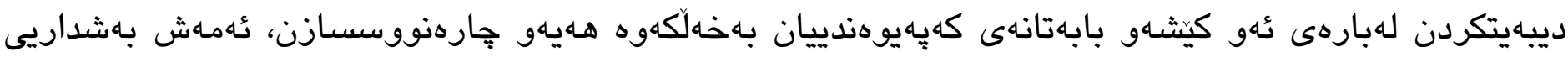

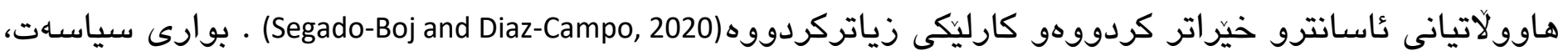

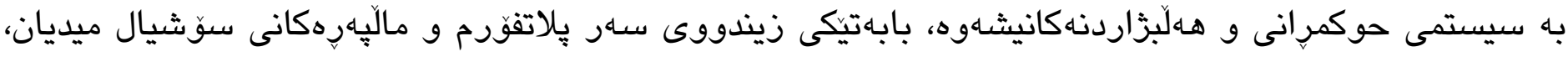

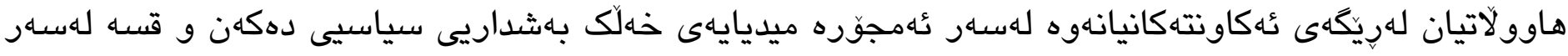

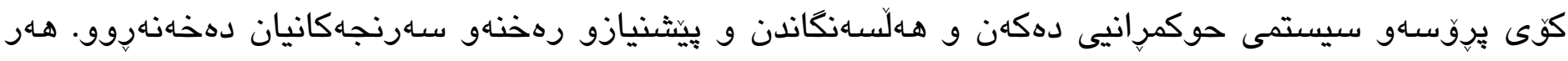

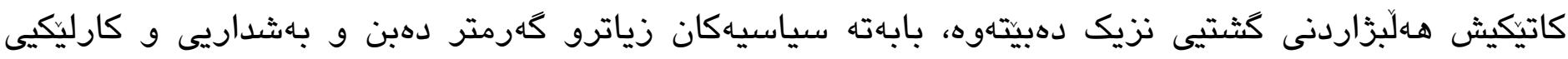

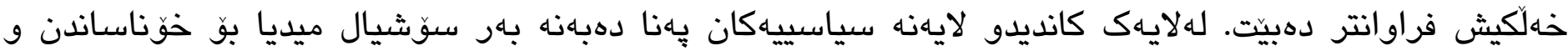

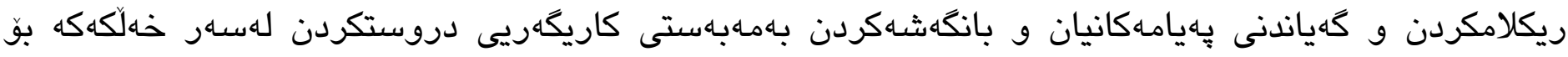

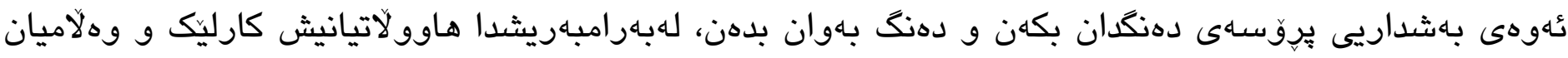

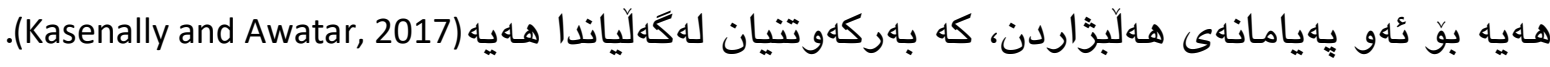

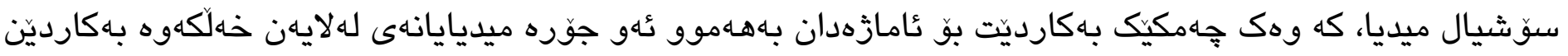

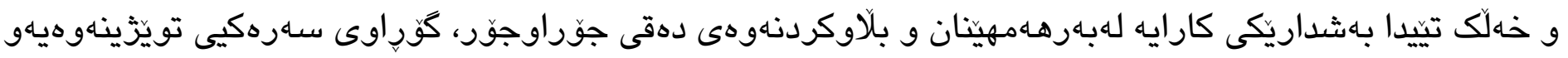

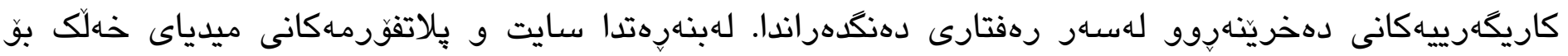

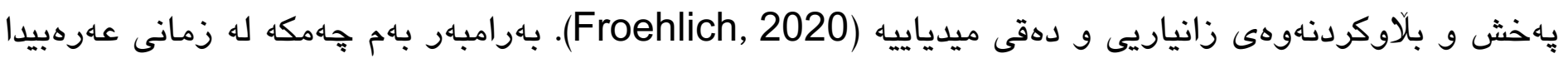

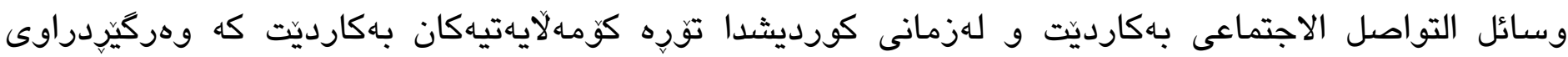

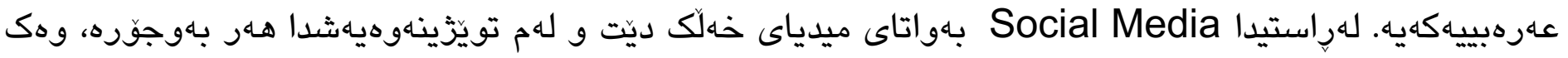

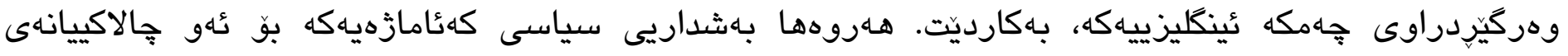

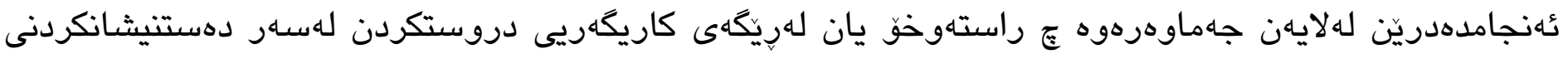

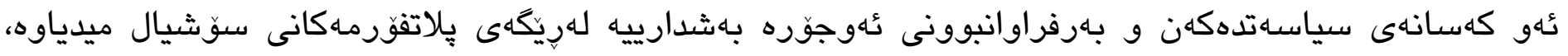

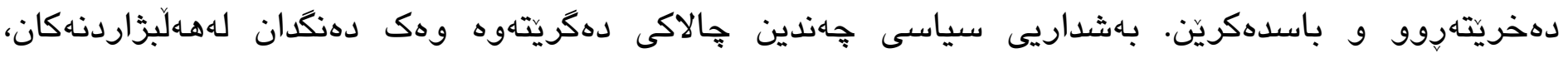

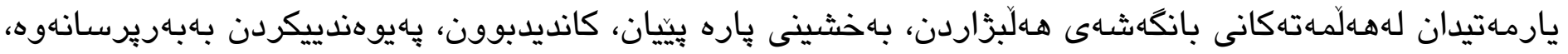

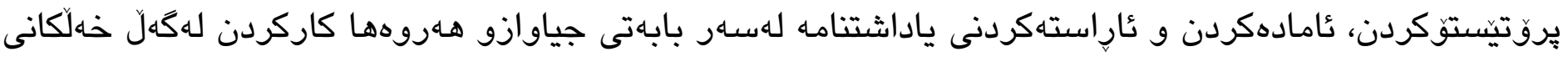


تر لهسهر دوّسيهو كيثـهكان، بهشداريى لهكارى ريكخراوهيى حزبى و سهانديكاو ياكيتيهكان و كانديدكردن و

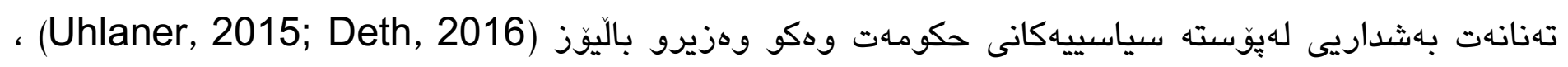

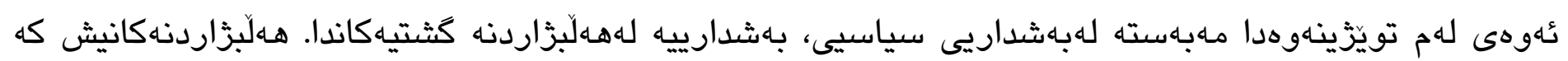

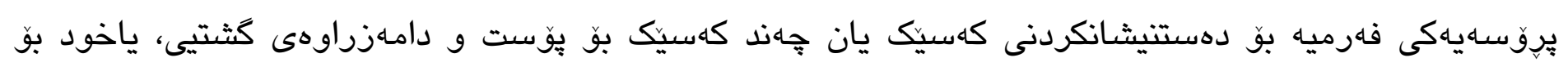

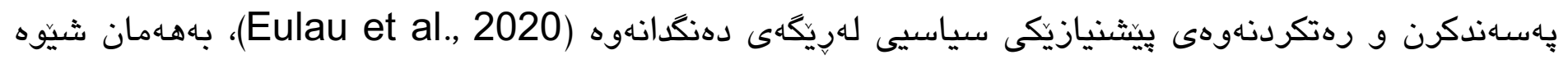

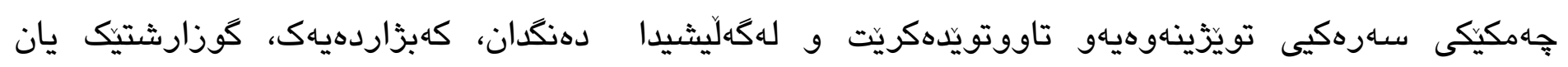

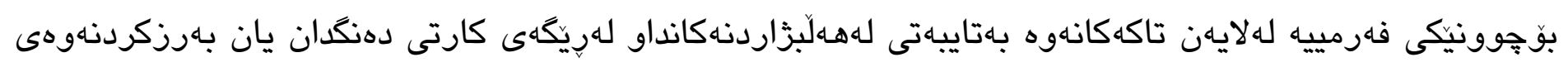

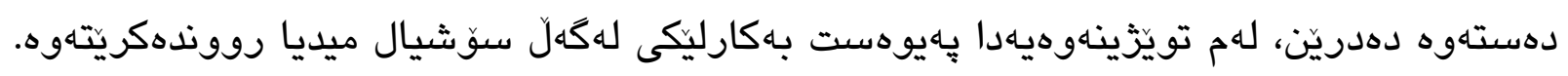

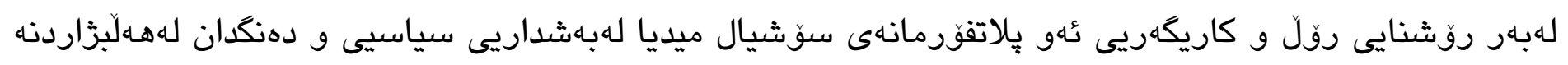

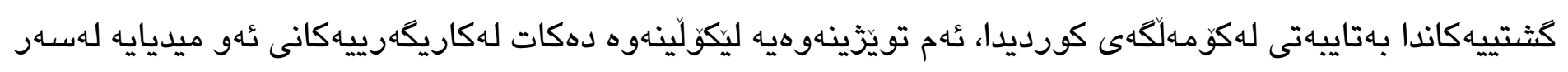

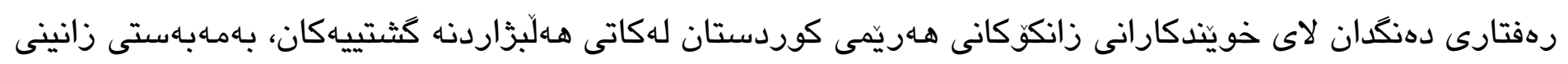

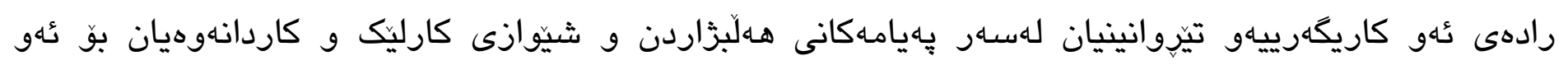
קֶיםيامانه.

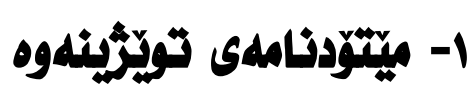

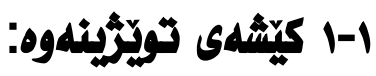

سوّثيال ميديا بوّته يهكيك لهباوترين بِلاتفورمهكانى نَالّوكوّىى زانيارى لهناو جهماوهرى كوردستانداو بهتايبهتيش

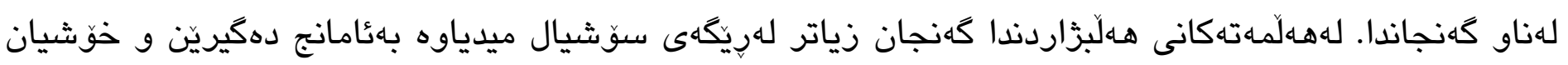

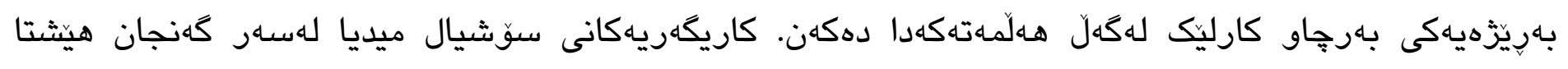

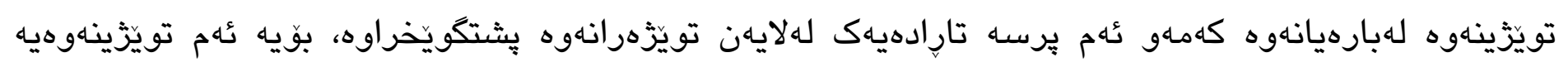

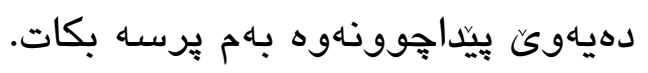

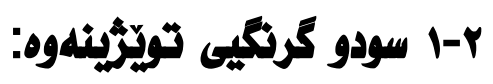

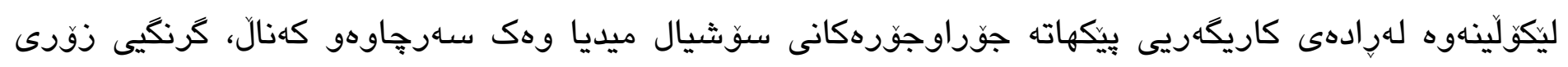

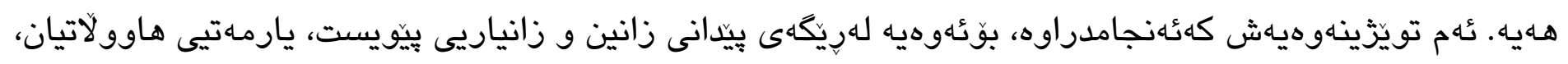

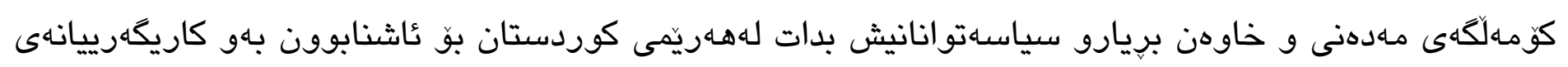


سوشيال ميديا هـيهتى لهسهر بريارو رهفتارمان له بوارى سياسهات بهتايبهتيش لهسهروبهندى هـلَّزَاردنهكانداو

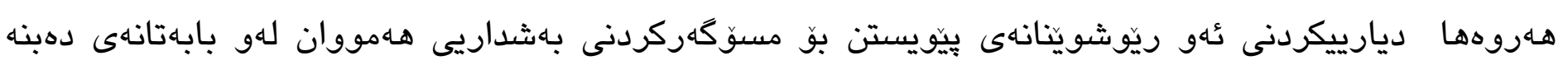

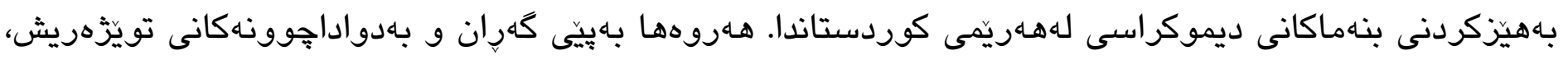

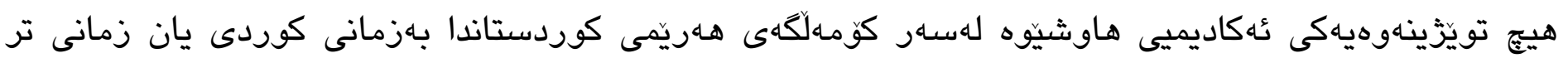

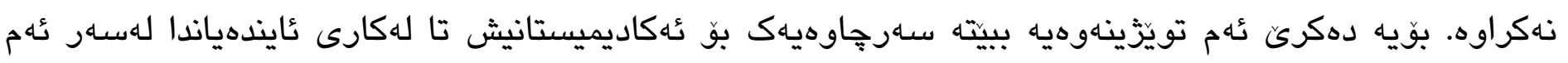
بواره سودى ليوهركرن.

\section{ب-ا هربياروكانى تويُّرينهوه:}

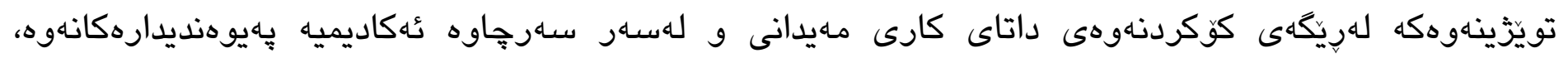

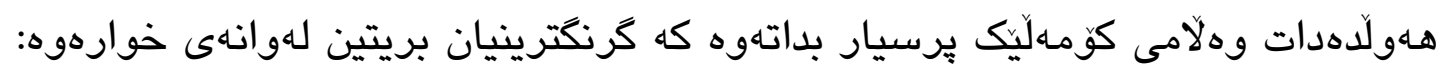

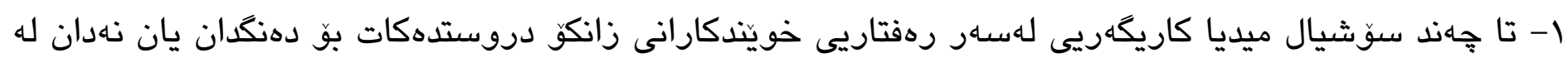
هـلَّزَاردنه كثتييه كاندا؟

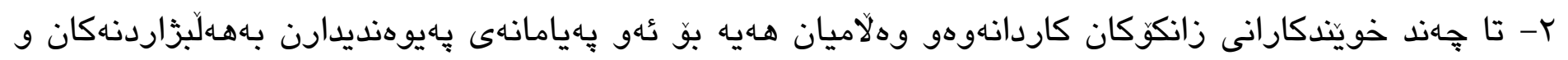

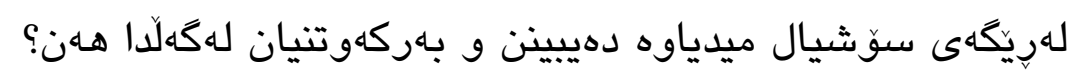

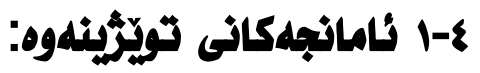

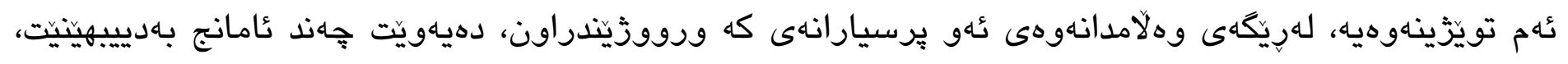
كه بريتين له:

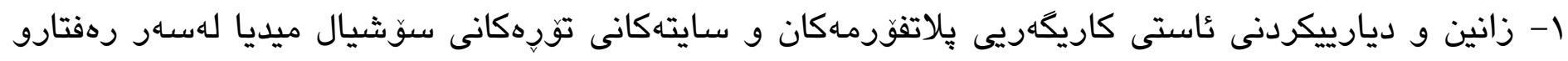

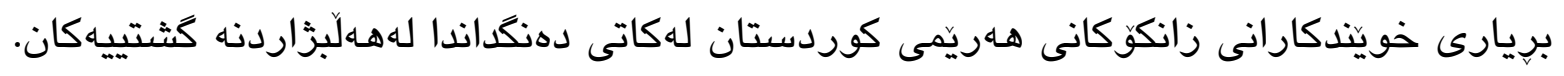

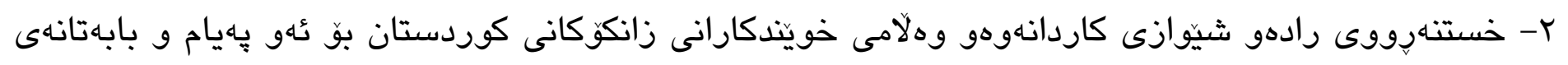

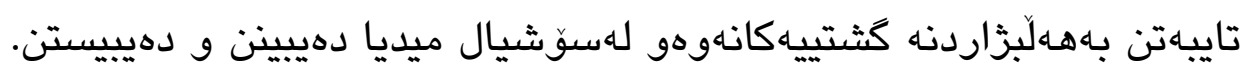

\section{ه-1 كريماثله تولئزينهوه:}

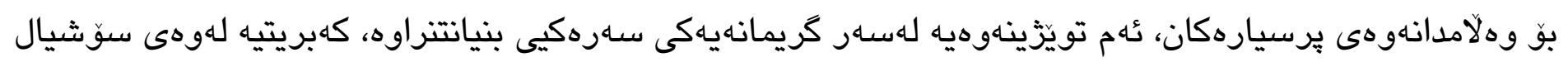

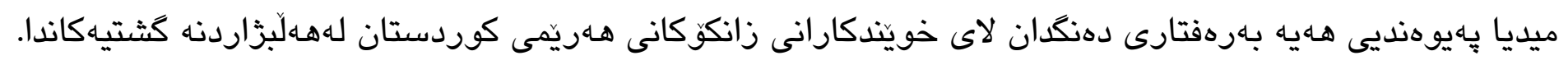




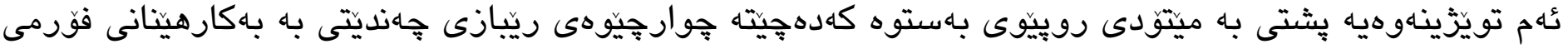

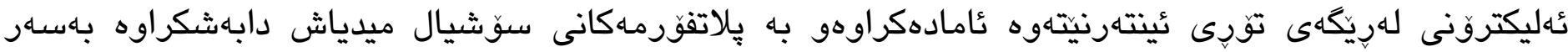
بهارشداريوواندا.

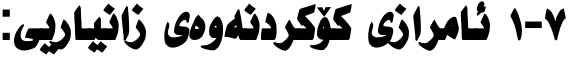

ئهم تويّزينهوهيه يشتى به دوو ئامراز بهستووه بو كوكردنهوهى داتاى مهيدانيى لهسهرجاوهى يهكهمهوه. ئامرازى

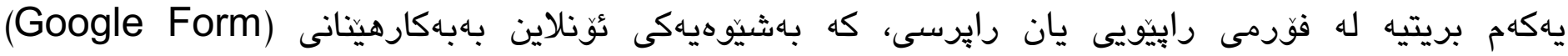

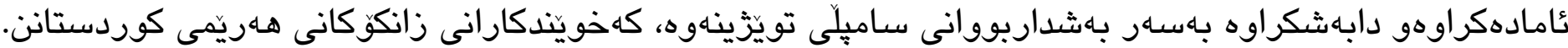

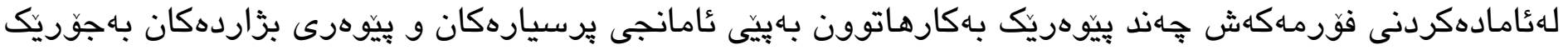
دانراون تا بهورديى رهفتارو نهريتى بهشداربووان تايبهت بهبابهتى تويّزينهوهكه، بيّيّويت.

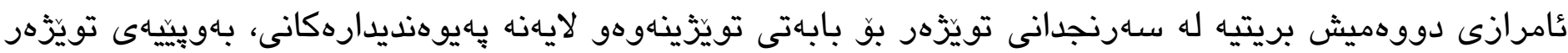

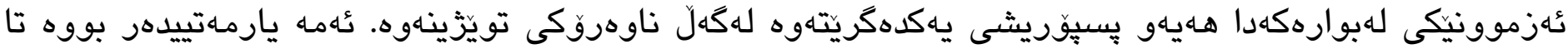

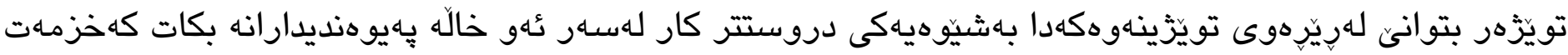

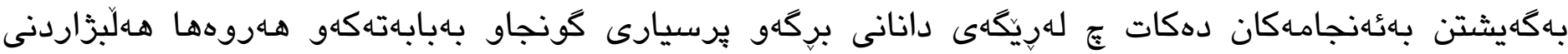

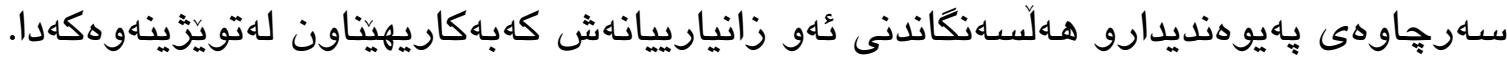

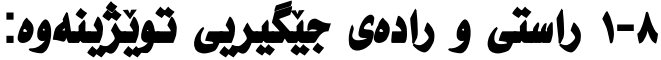

بو دلّنيابوونهوه لهدروستيى و كارايى رابرسييهكهو كونجانى برسيارو بركهكانى و شياوييان لهكهل بابهتى تويزّينهوهكهو بهمهبهستى كهيشتن به راستيى تويزّينهوه، بهجوريكيك بييته مايهى دهستكهوتنى ئهنجامى وردو راستاقينه، فوّرمى رايرسييهكه يِيش دابهشكردن و ناردنى بو بهشداربووان، بهمهبهستى هـلَّهانكاندنى نيّردرا بو جهند شارهزاييهكى زانستيى تاييهتمهند بهبوارهكه. دواى كاهيشتهوهى تيبينى و سهارنجاهان لهلايهن شارهزايانى

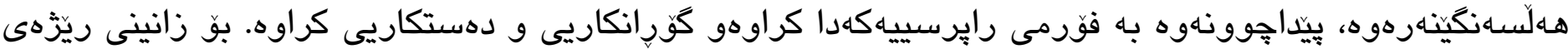

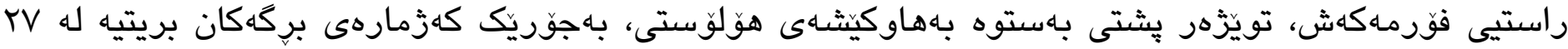

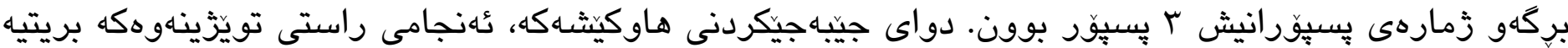

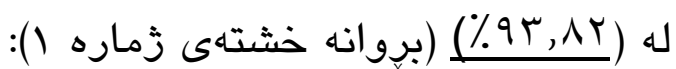




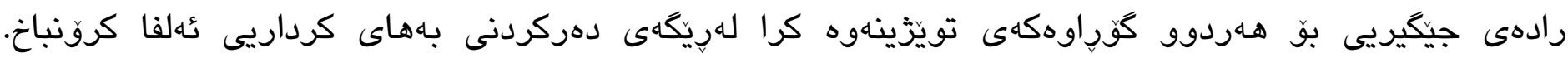

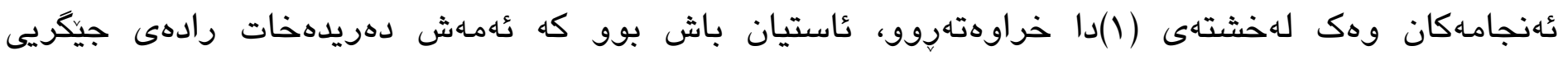
تويَزينهاوهكه باشها.

\begin{tabular}{|c|c|c|}
\hline راستى تويّزينهوه & زَمارهى بِيَّرَان & زمارهى بركهكان \\
\hline$\% 9 r . \wedge r$ & $r$ & $r V$ \\
\hline بههاى ئهلفا كرونباخ & زمارهى بركَكان & كُّراوهكان \\
\hline$\cdot, \vee>70$ & 7 & سؤشيال ميديا \\
\hline$\cdot, \vee \cdots$ & $\Lambda$ & رةقفتاري دةنطدان \\
\hline
\end{tabular}

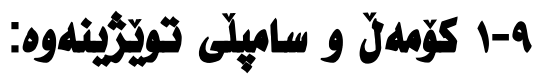

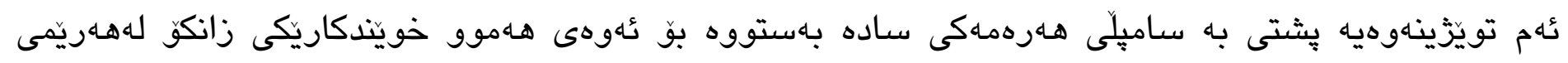

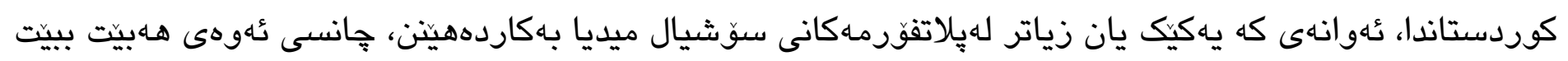

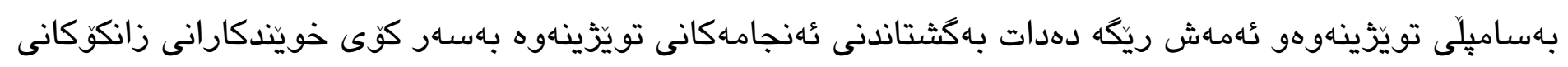

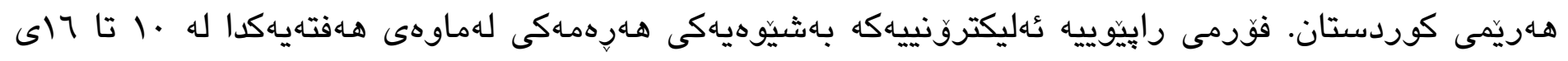

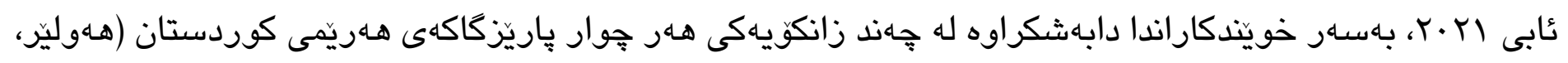

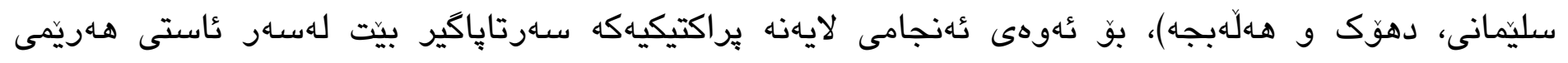

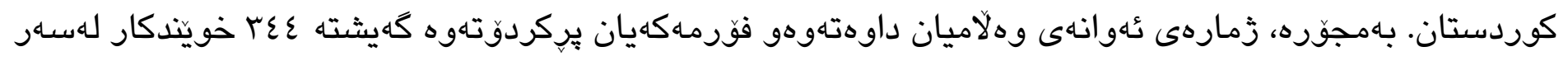

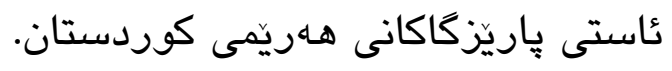

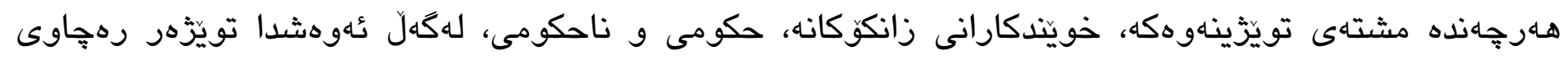

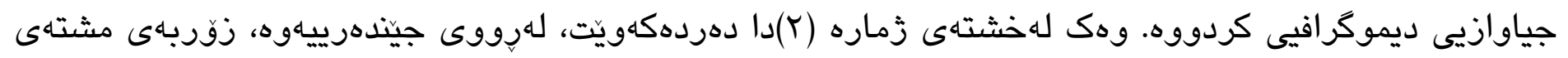

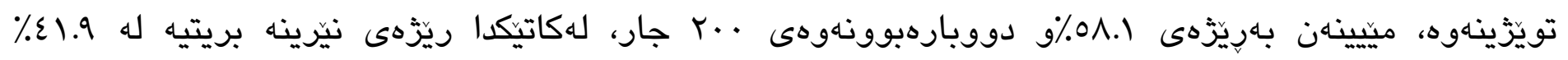

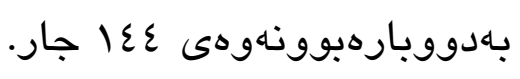

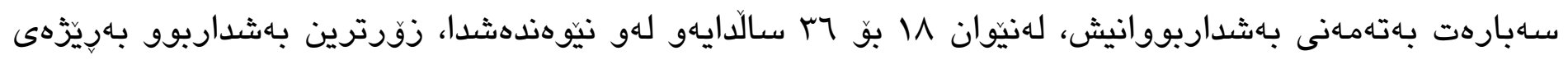

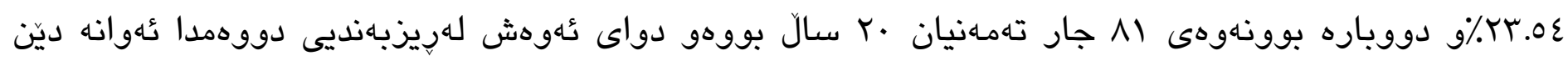

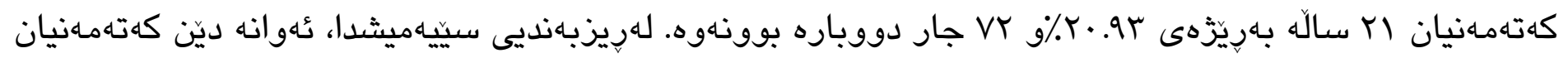

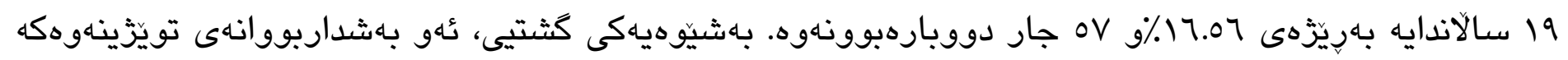

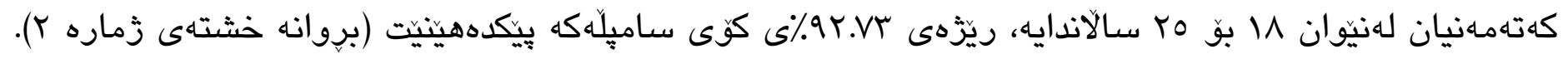




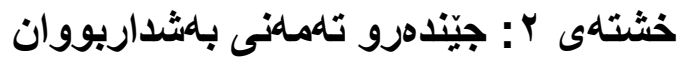

\begin{tabular}{|c|c|c|}
\hline ريّزَه & دووبار مبوو نهوه & جيّندهر \\
\hline$\%$ \% . 9 & $1 \leq \varepsilon$ & نيّر \\
\hline$\% 0 \wedge .1$ & r.. & مئ ل مئ \\
\hline$\% 1 \ldots$ & $r \leqslant \varepsilon$ & كوّ \\
\hline ريَّْه & دووبار هبوو نهوه & تامهان باسالّ \\
\hline 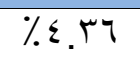 & 10 & 11 \\
\hline$\% 17.07$ & OV & 19 \\
\hline$\% r r .94$ & 1) & r. \\
\hline$r \cdot .9 T$ & VT & YI \\
\hline$\% 9.09$ & זr & rr \\
\hline$\% 9.09$ & זr & $r \mu$ \\
\hline$\% 0 . r^{\mu}$ & 11 & $r \varepsilon$ \\
\hline$\%$ \%. 9 & 1. & To \\
\hline \%.r.T & $\Lambda$ & rT \\
\hline$\% 1.17$ & $\varepsilon$ & TV \\
\hline$\% \cdot .01$ & $r$ & rA \\
\hline$\% \cdot r^{q}$ & 1 & rq \\
\hline$\% \cdot .01$ & r & $r$. \\
\hline$\cdot r^{9 q}$ & 1 & rI \\
\hline$\cdot r^{9}$ & 1 & Tr \\
\hline- & - & Tr \\
\hline$\% \cdot . \wedge \mathrm{V}$ & $r$ & $\Gamma \varepsilon$ \\
\hline .01 & $r$ & ro \\
\hline$\% \cdot r^{q}$ & 1 & ד \\
\hline$\% 1 \ldots$ & $r \leqslant \varepsilon$ & كَّ \\
\hline
\end{tabular}

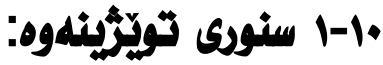

سنورهكانى ئهم تويَّينهوهيه بهسهار جهاند بواريَكا دابهشبوون، بهمشيّوهيهى لاى خوارهوه:

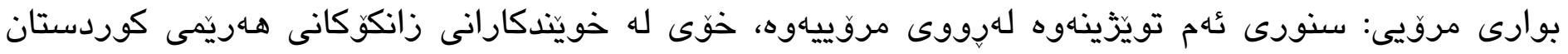

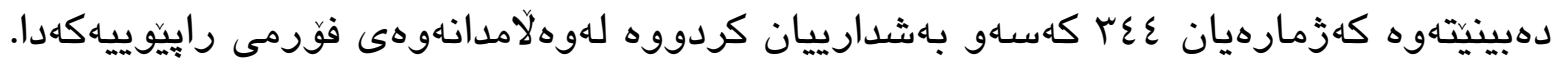

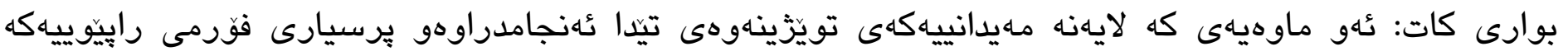

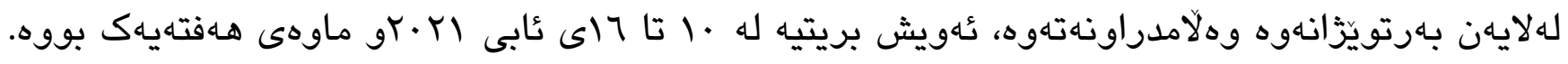

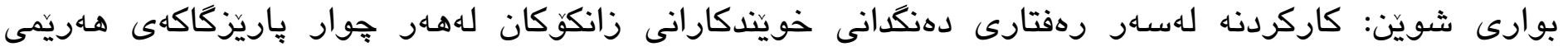
كوردستان. 


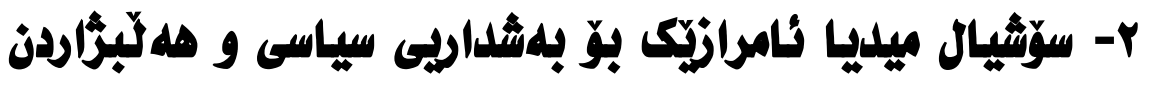

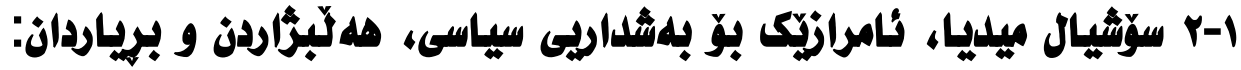

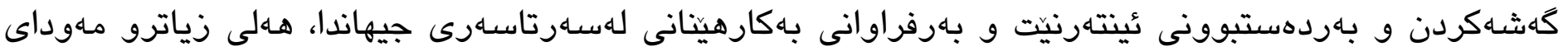
زور فراوانترى رهخساندوه بو بهشداريى زياترى هاوولاّتيان لهبيرورا دهربرين و دهرخستنى هـلويّيتيان لهسار

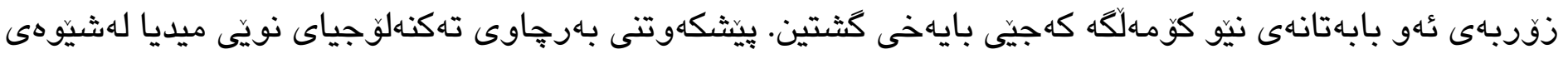

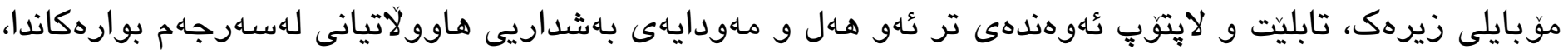

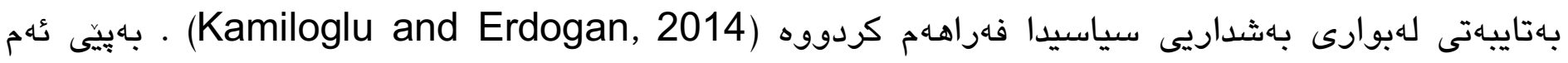

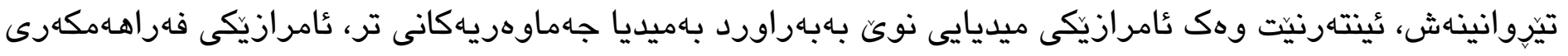

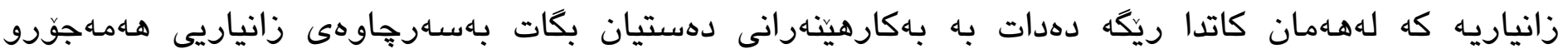
بيرويوجوون و ديدى هـماهجهشن. ئه زانيارى و بيروياوهره هـهمهورانهش، توانايهى زياتر دهبهخشن

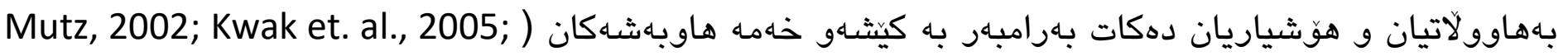

.(Bannet and Lyengar, 2008

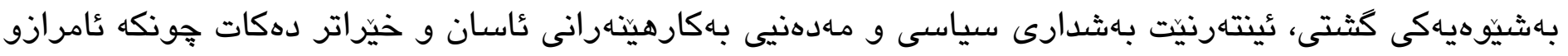

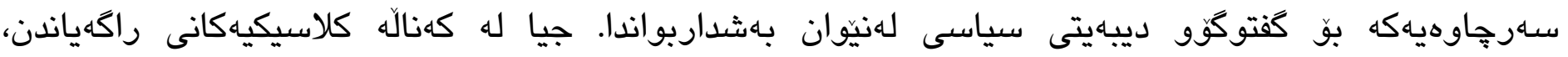

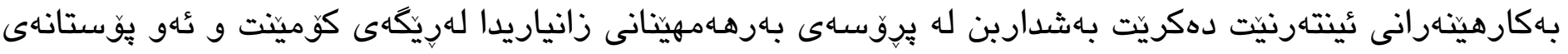

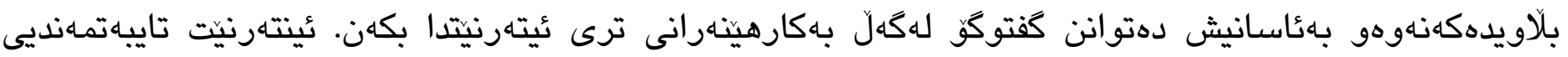
ئهوهى هـيه كه ئازادهو خودباريّوهبهره، كهئهمهاش لهراستيدا نيشانهو جيّيهنجهيهكى ديموكراسيى راستهقينهيه

(Baran, 2010)

هـنديك لهشارهزايان، بِاتفورمهكانى سوّشيال وهك كوزارشتيك بو بهليبرالكردنى دوحى ئينتهرنيت دهبين و

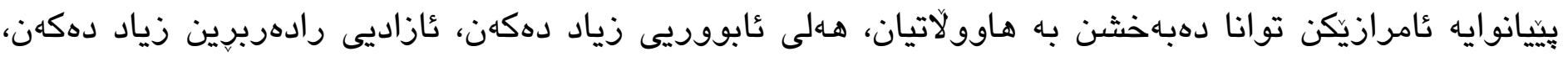

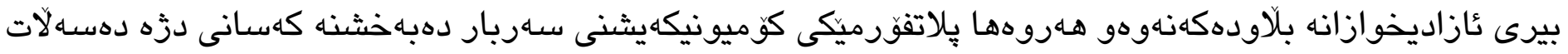
(Schleffer and Miller, 2021)

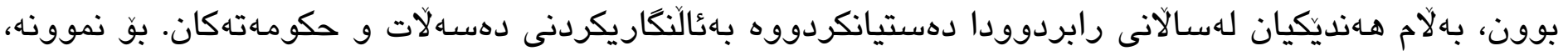

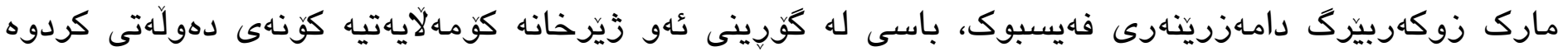

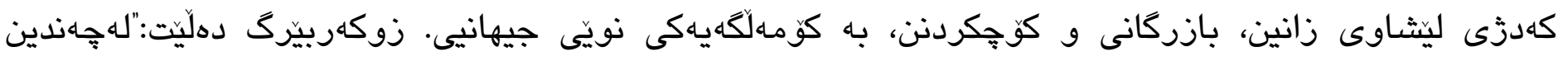

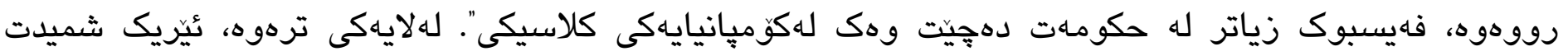

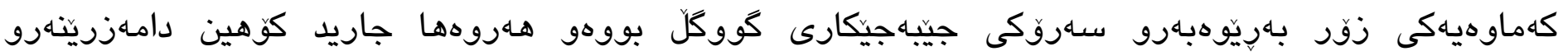




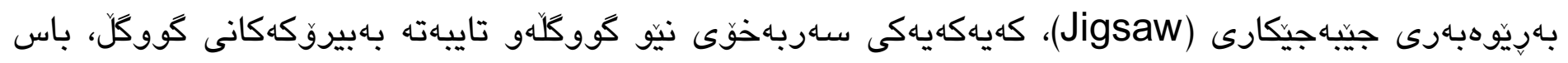

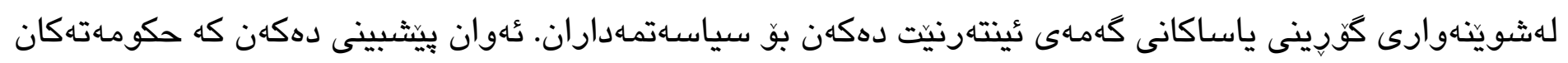

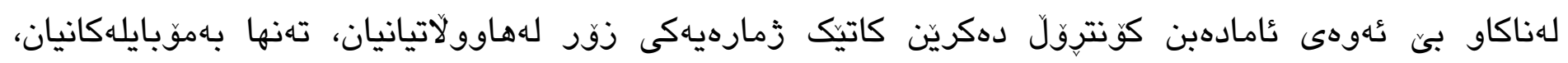

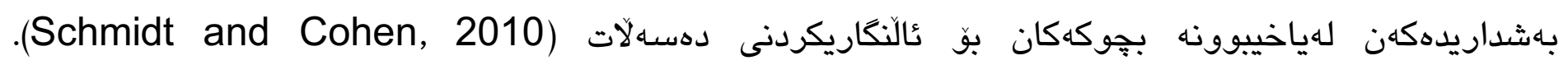

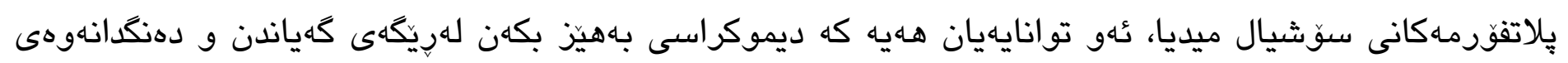

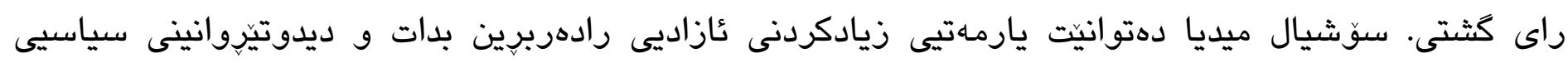

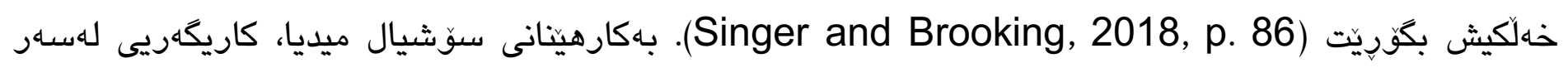

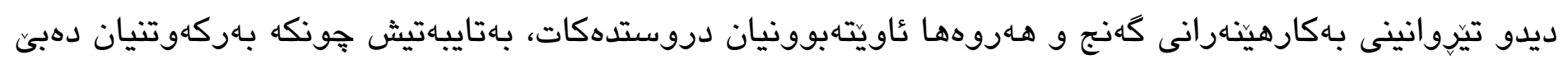

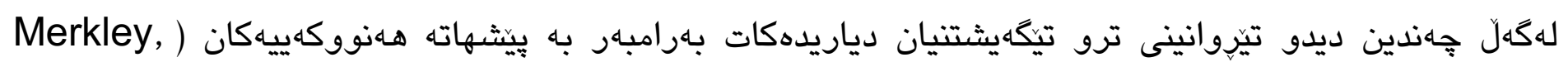

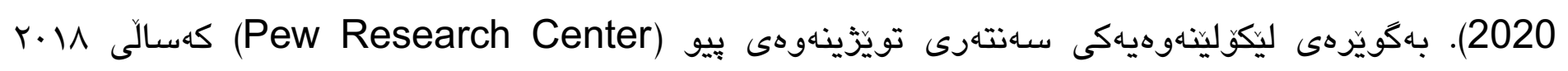

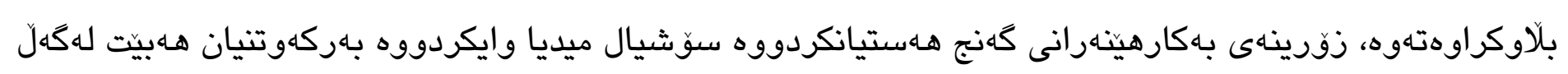

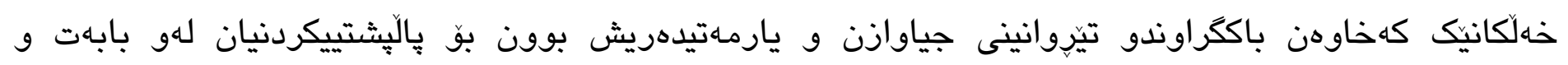
بيشثهاتانهى كرنكن بوّيان (Pew Research Center, 2018).

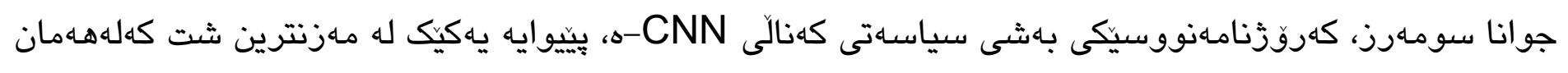

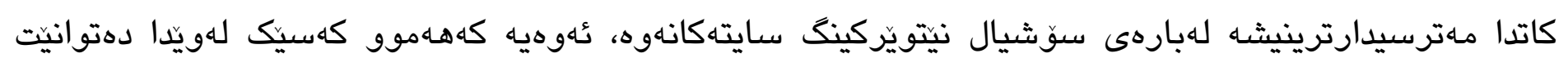

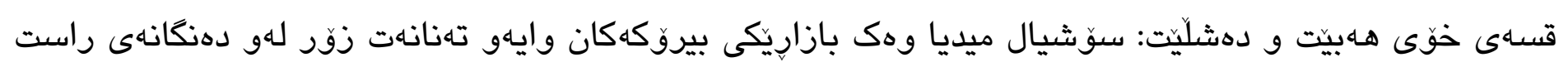

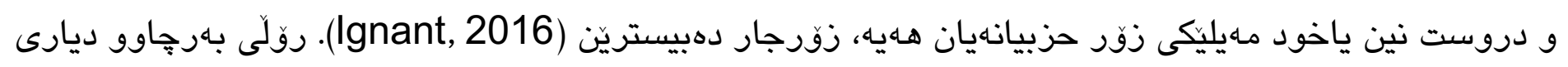

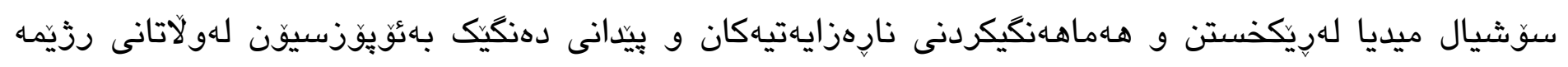

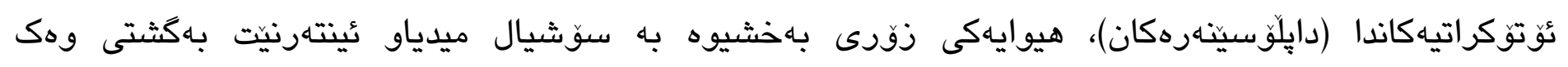

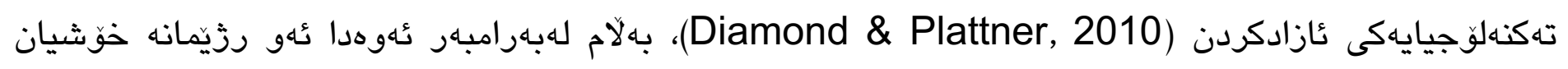

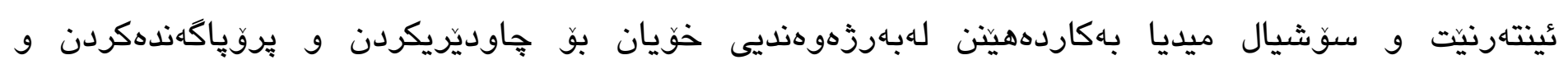
دوورخستنهوهى سـرنجى دهنكدهرانيش لهكانديده سياسيهكان (Zhuravskaya, 2020).

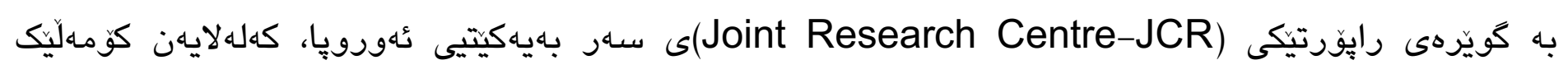

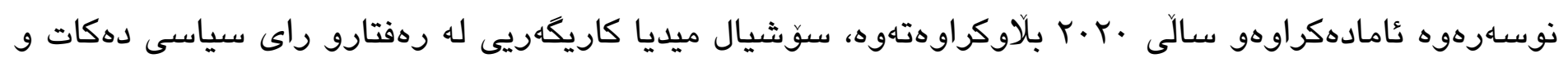

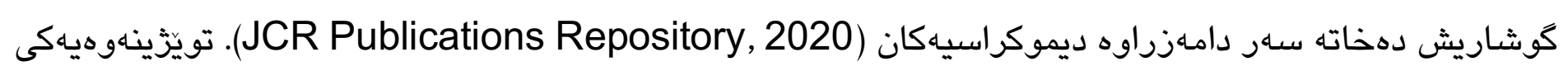

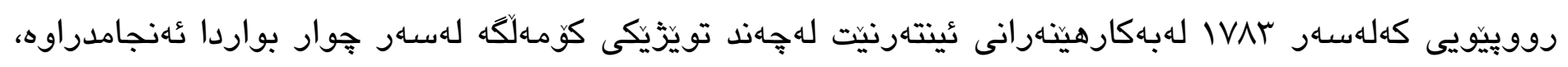

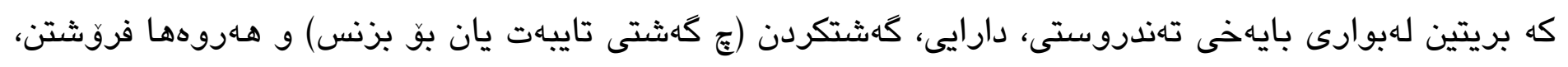

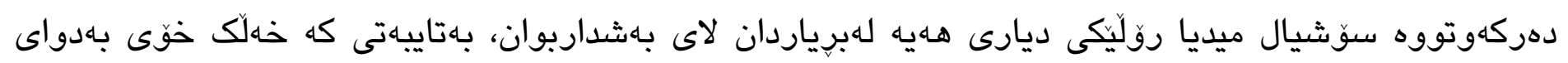




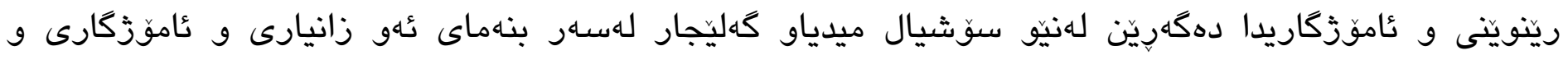
رينوينيانهى لهويَ بلاودهبنهوه، بريارهكانمان دهدهين (Distaso and Mccorkindale, 2017).

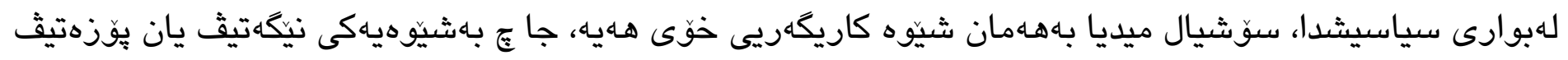

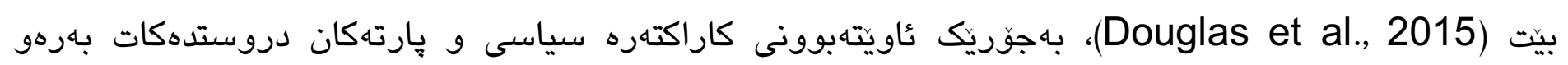

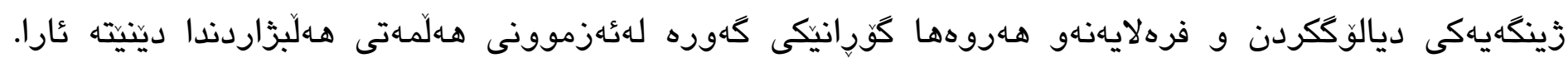

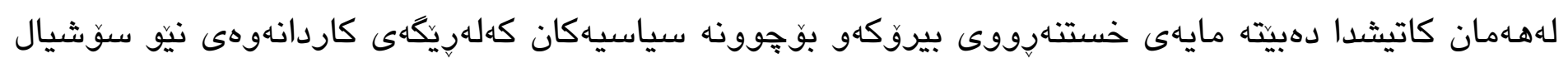

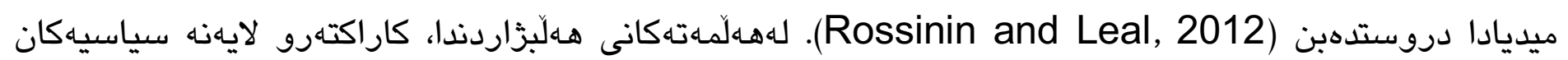

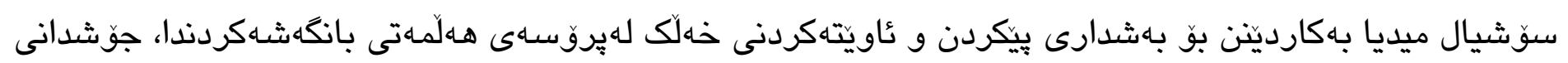

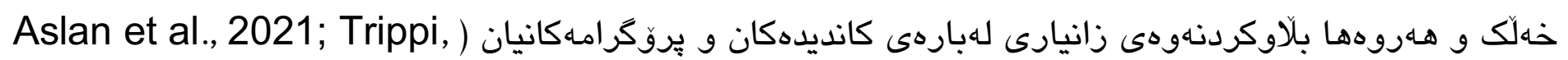

\section{r-r كاريكلريى سوّثيال ميليا لهسلهر روقتارى دمثكدان:}

لهسهروهختى دهنكدانهكاندا، زوّريك لهكانديدان و لايهنكران و لايهنه سياسيهكانيش بهنا دهبهنه بهر سوّشيال ميديا

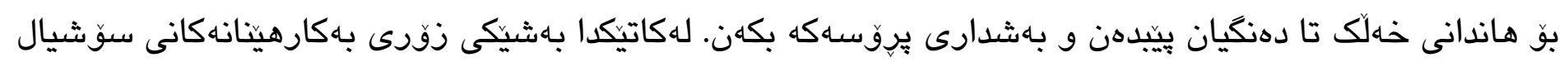

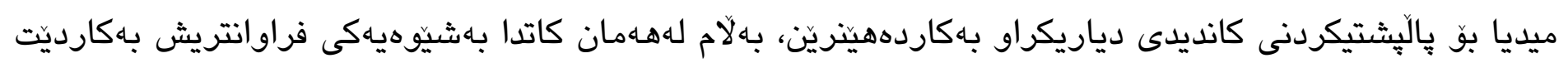

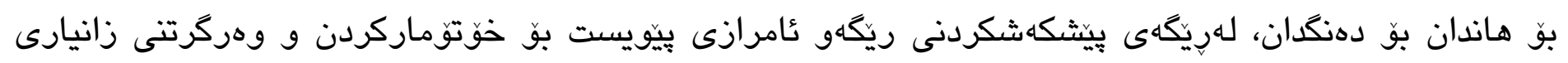

بيّويست بوّ شيّوازو جِوَنيهتى دهنكدان (Smith, 2020).

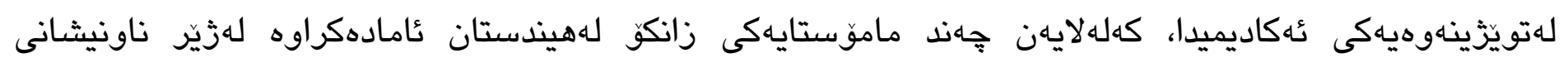
كاريكهريى سوّشيال ميديا لهسهر ردفتارى دهنكدان (Influence of social media on voting behavior)،

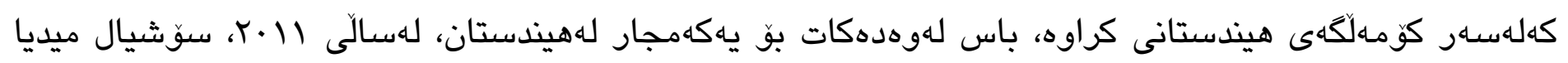

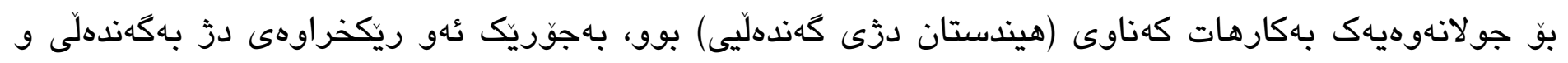

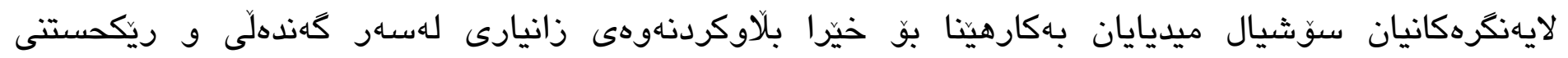

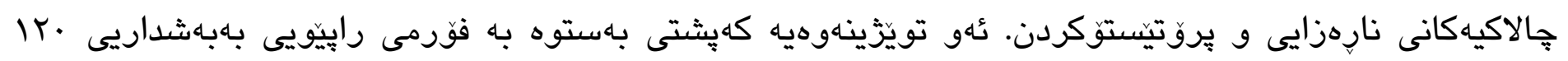

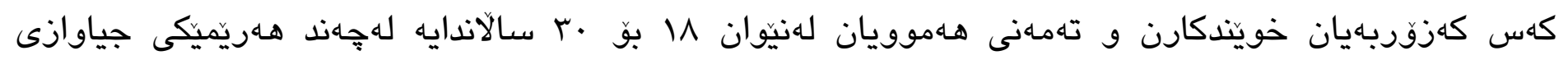

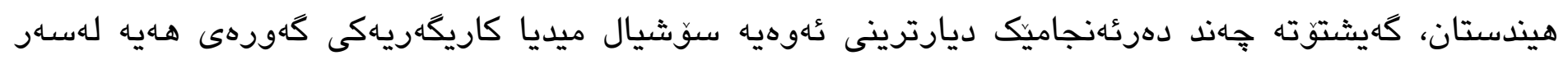

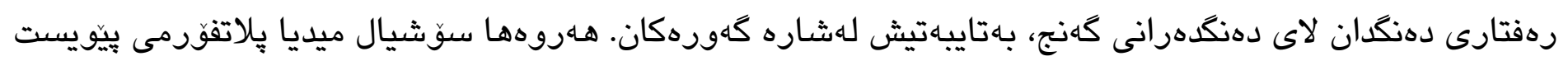

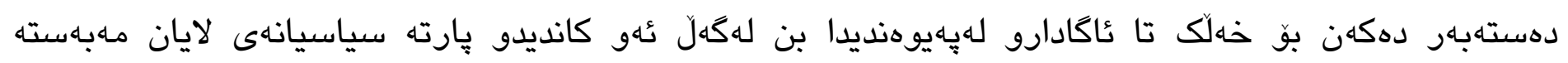

.(Biswas et al., 2014, p.153) 


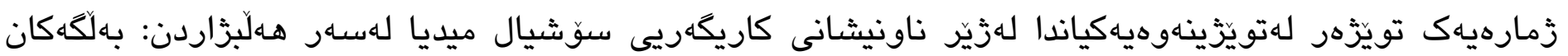

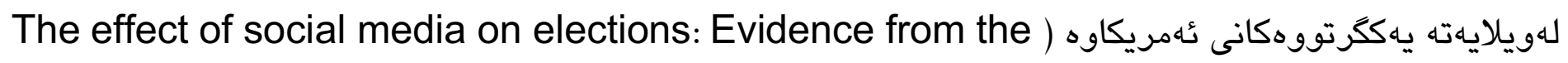

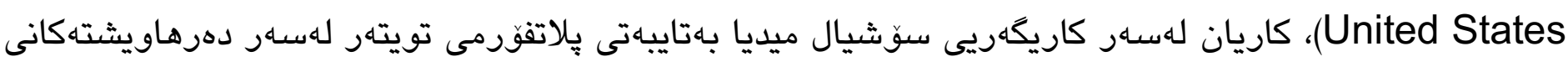

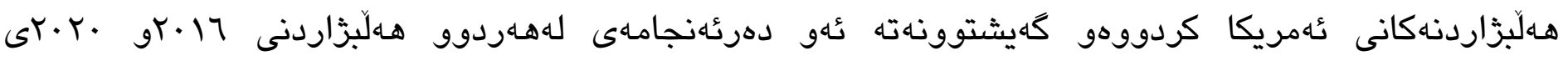

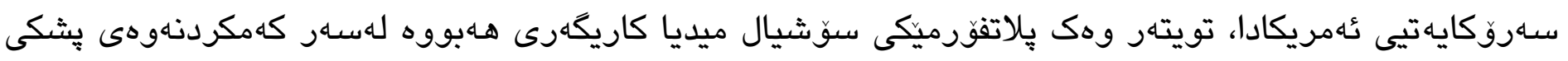

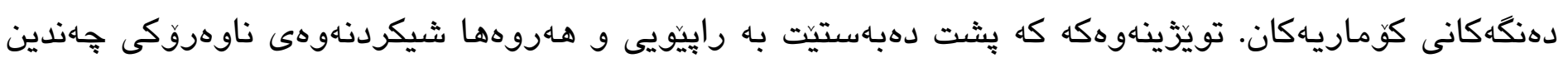

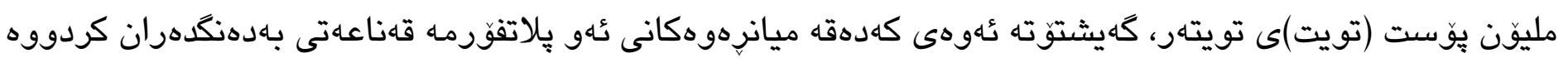

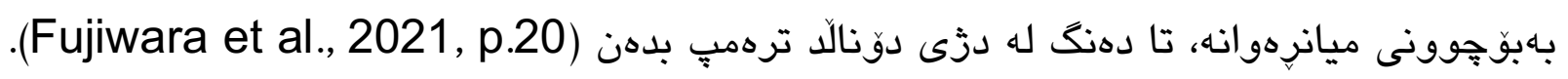

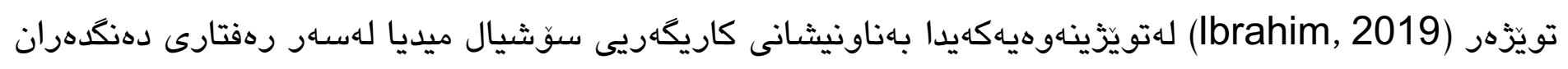

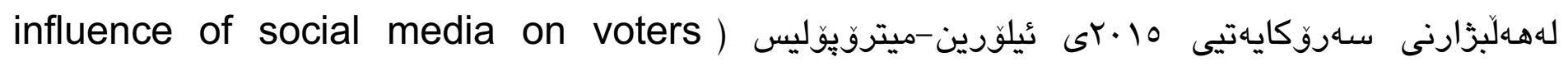
behavior in the 2015 presidential election in Ilorin-Metropolis

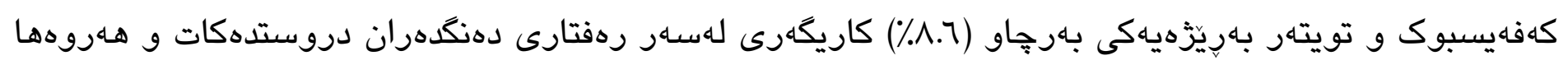

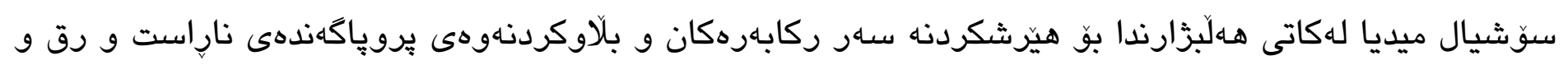

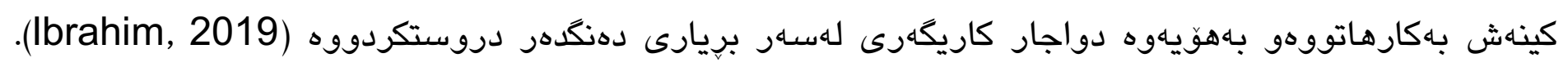

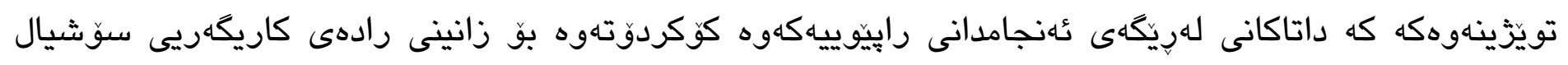

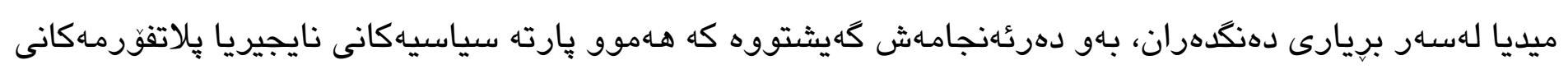

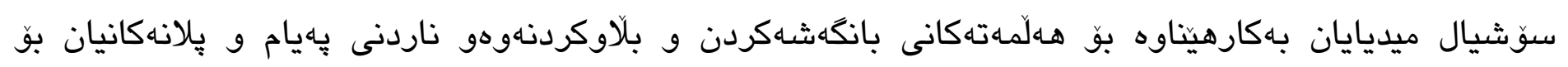
لايهنكرانيان.

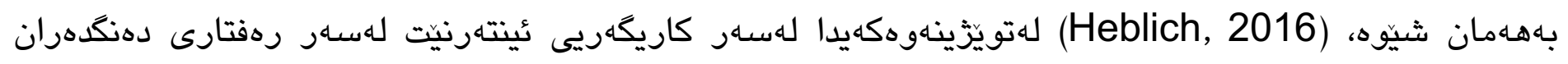

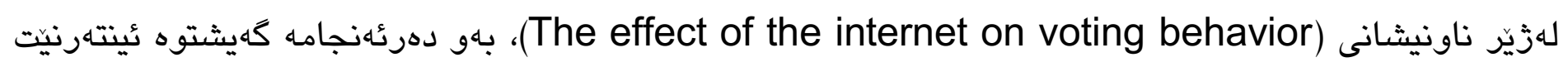

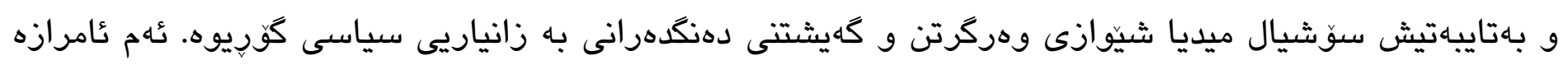

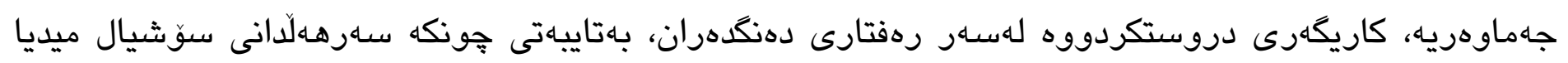

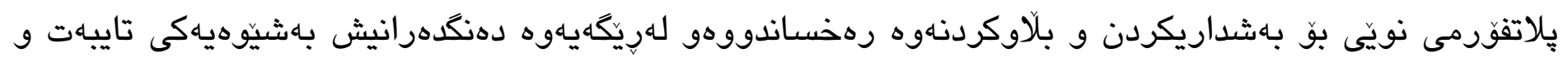

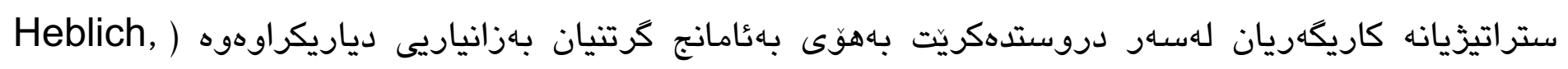
(2016

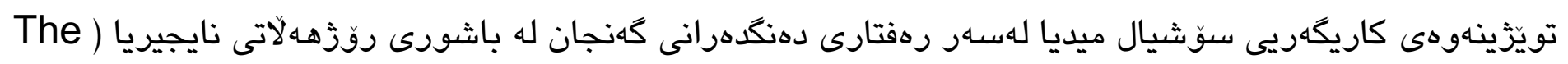
(influence of social media on the voting behavior of the youth in South East Nigeria

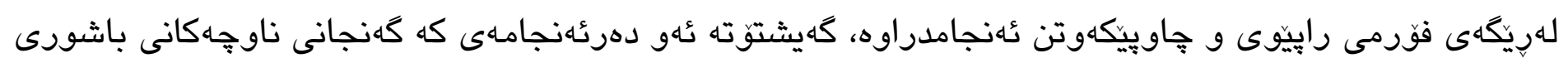




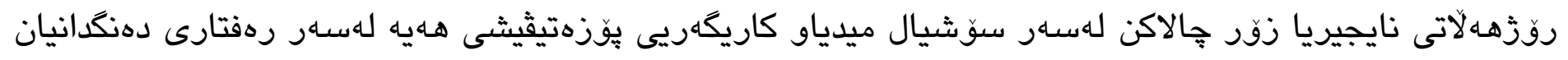

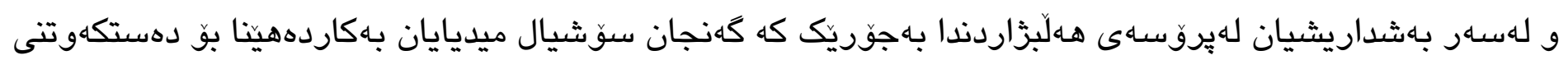

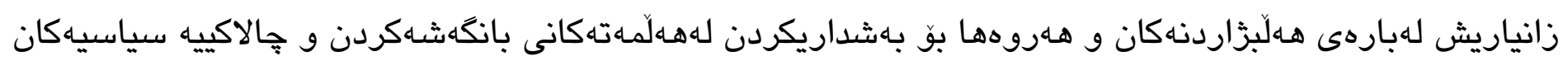

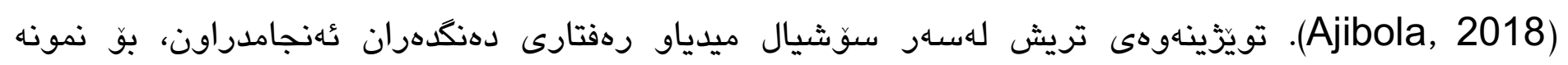

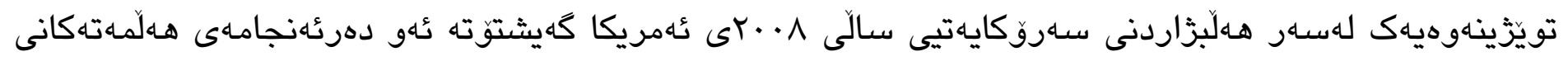

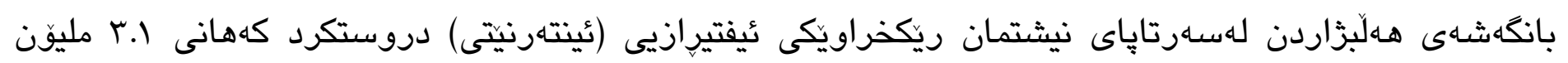

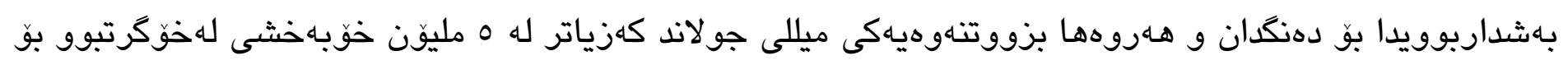

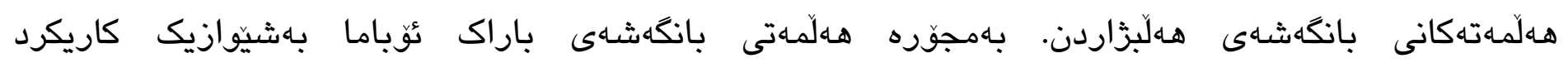

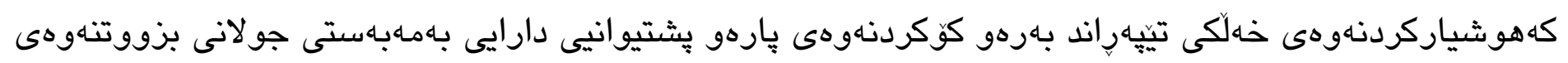
ميللى و زيادكردنى بهشداريى سياسى (190-189.18.,pogburn and MathildeVasquez 2011).

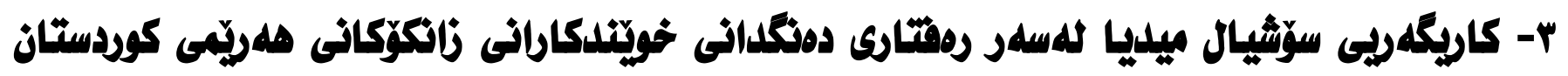

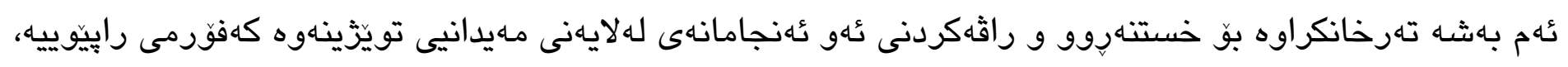

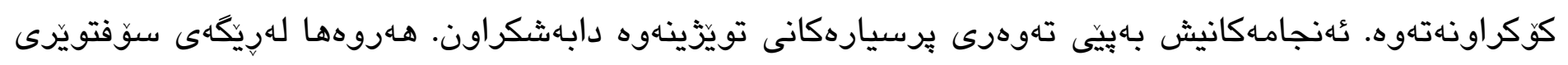

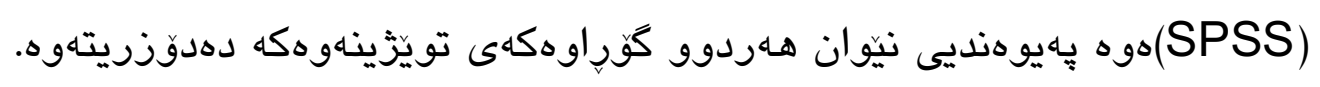

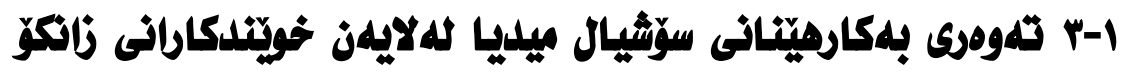

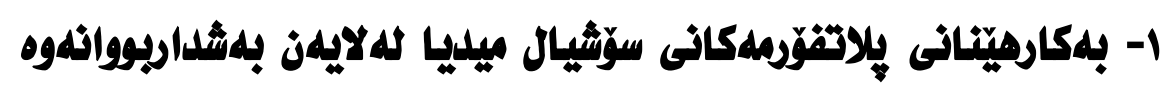

\begin{tabular}{|c|c|c|}
\hline ريّزه & دووبارهبوونهوه & يلاتفقَرم \\
\hline \% \% & rq. & فهيسبوك \\
\hline$\% 19.4$ & 77 & تويتهر \\
\hline$\% \vee 9.7$ & TVE & ئينستاكرام \\
\hline$\%$ \% & ros & سنايڤجات \\
\hline$\%$ ०V.7 & 191 & يوتيوب \\
\hline$\% \varepsilon .1$ & $1 \varepsilon$ & لينكيدئين \\
\hline \%YY.V & V^ & تيكتوك \\
\hline IV.乏 & 7 . & هيتر \\
\hline
\end{tabular}




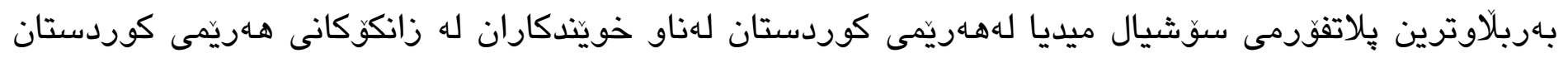

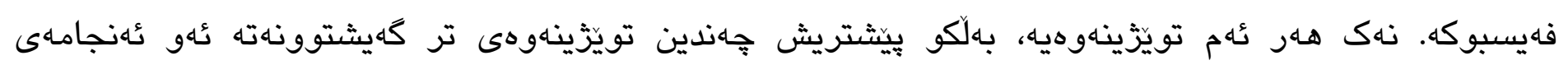

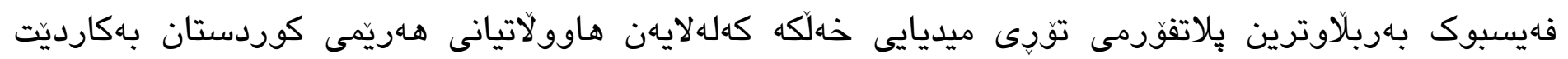

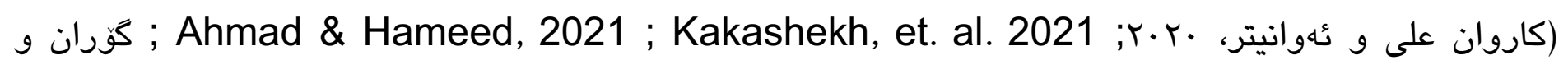

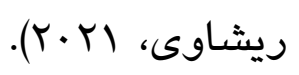

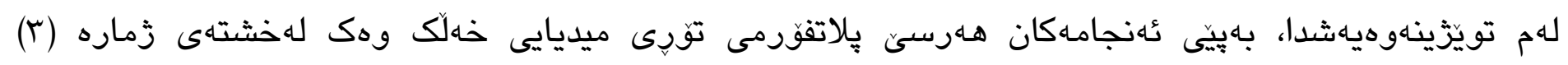

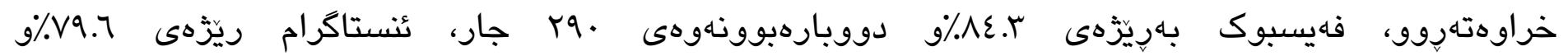

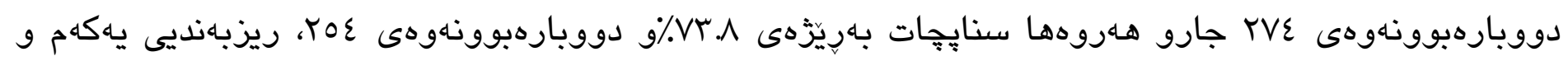

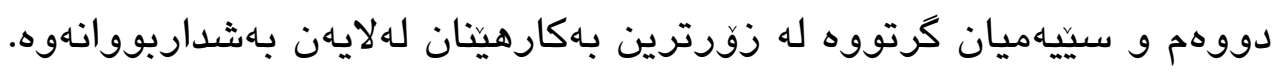

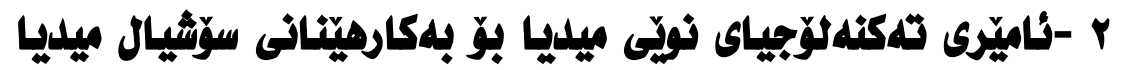

خشتهى ع: بهكارهينانى ئاميّرهكانى تهكتهلوزيا بو سوّشيال ميديا

\begin{tabular}{|c|c|c|}
\hline ريّزَه & دووبارهبووناهوه & ئامراز \\
\hline$\% 91$ & TrV & موّبايلى زيرهك \\
\hline \% $/ Y \varepsilon . \varepsilon$ & $\wedge \varepsilon$ & لإيتوّب \\
\hline$\%$ \%.q & 1. & كوّميِيوتهرى سـهرميزز \\
\hline$\% \varepsilon . q$ & IV & تُوِيليت (ئاييادو \\
\hline
\end{tabular}

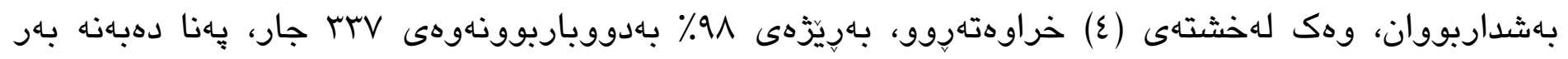

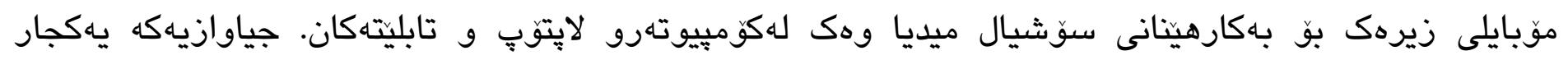

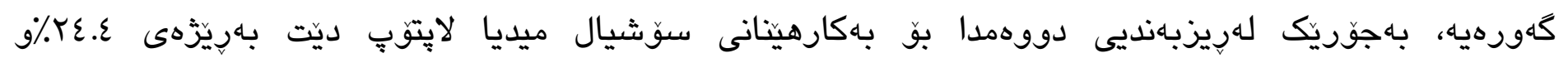
دوويارهبوونهوهى تهنها ع^ جار. 


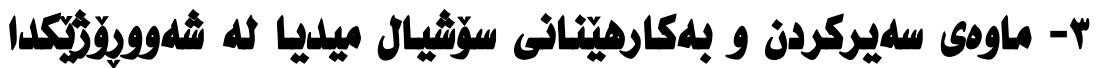

خشتهى 0: ماوهى بهكارهينان و سهيركردنى سوشيال ميديا لهروزيكدا

\begin{tabular}{|c|c|c|}
\hline ريّزَه & دووبارهبوونهوه & ماوه \\
\hline$\%$ & V & نزيكاءى •r خوله \\
\hline$\% 11$ & ґN & نزيكهى ا كاتزَميّر \\
\hline$\% 17.7$ & oV & نزيكهى r كاتزَميّر \\
\hline$\%$ \%.V & 10 & نزيكهى r كاتزميّر \\
\hline$\% \varepsilon 0.7$ & $10 \mathrm{~V}$ & ع كاتزّميّرو زياتر \\
\hline$\% 1 \ldots$ & $r \varepsilon \varepsilon$ & كو \\
\hline
\end{tabular}

ريّزديهكى زور له بهشداربووانى تويَزْينهوهك، وهك لهخشتهى (0) خراوهتهوو، جوار كاتزميّرو زياتر لهشهاوو

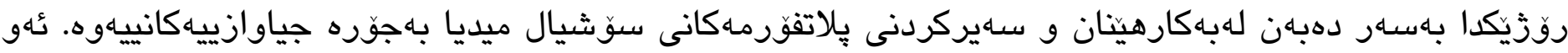

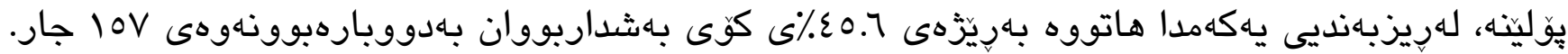

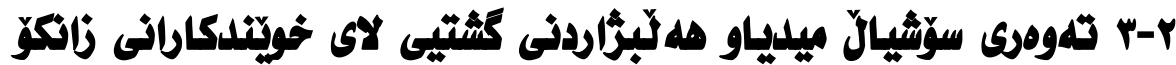

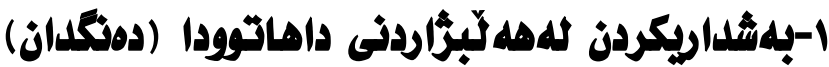

خشتهى1: بهشدارييكردن لهههلبرّاردنى داهاتوودا

\begin{tabular}{|c|c|c|}
\hline ريّزَه & دووبارهبوونهوه & \\
\hline$\%(21.9$ & $1 \varepsilon \varepsilon$ & بهلّلى \\
\hline$\%$ \%.9 & $1 . r$ & نهخيّر \\
\hline$\%$ \% & $9 \mathrm{~V}$ & 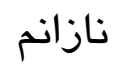 \\
\hline$\% 1 \ldots$ & $r \varepsilon \varepsilon$ & كو \\
\hline
\end{tabular}

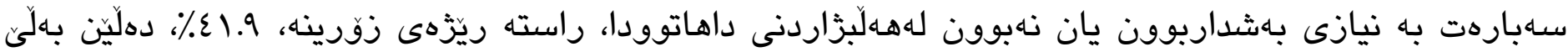
بهشداريدهكهن لهدهنكداندا، بهلام ئهوانهى كه دهلّين بهشداريى ناكهين (ريّزّهى 9.9\%٪)و ئهوانه كه دوودلّن و

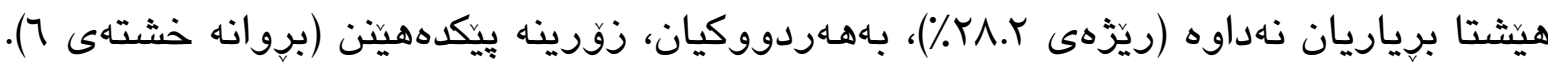


خشتهى V: هوَكارهكانى بهشدارينهكردن لهدهنكداندا

\begin{tabular}{|c|c|c|}
\hline ريّزْه & 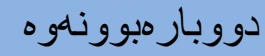 & \\
\hline$\%$ Y. 1 & $V \varepsilon$ & يروّكر امى كانديدو لايهنه باشثداربوو هكانم به دلّ نييه \\
\hline$\% 71$ & $1 \wedge$. & متمانهم به بالِّيّن و كفتى كانديدو لايهنه باششداربو هكان نبيه \\
\hline$\% \leqslant q . Y$ & $1 \leq 0$ & 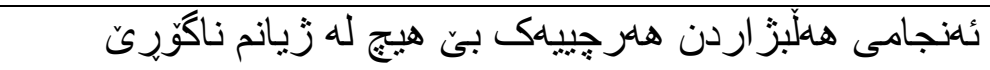 \\
\hline$\%$ or.o & 100 & دهنكدانم سودى نييه جونكه ساختهكاريى دهكريّت له هلَّبزْ اردن \\
\hline \% T.Y & 90 & كانديدهكانى هالّبزْ اردن بهكثتيى كهسانى شياو نين \\
\hline$\%$ \%.V & $11 \mathrm{~V}$ & 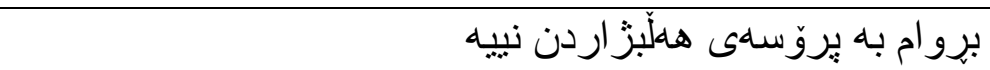 \\
\hline$\%$ \% & 17 & جاو هرو انيى للريزى دهنحدان بيّز ارم دهكات \\
\hline$\%$ \% $\varepsilon$ & V & ناز انم شويّنى بنكهى دهنحدانم له كويّيه \\
\hline$\%$ \% & 01 & كات و وزهى خوّم باهفيروّ نادهم بوّ دهنكدان \\
\hline$\% 1 r .7$ & $\varepsilon$. & ناوى خوّم توّمارنـكردووه له كوّ مسيوّنى هالَّلَزْ اردن \\
\hline$\% 1 \cdots$ & & كوّ \\
\hline
\end{tabular}

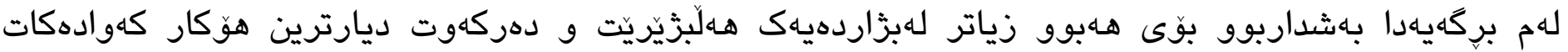
بهشدارينهكهن لهدهنكاندا، بريتيه لهنهبوونى متمانه، ع بهابلّينى كانديدو لايهنه سياسيهكان ياخود بهخودى

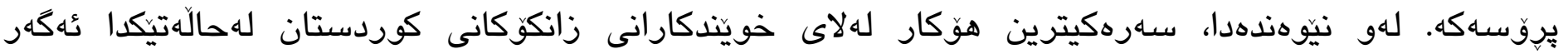

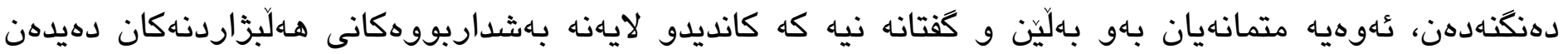

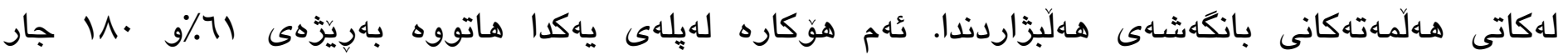

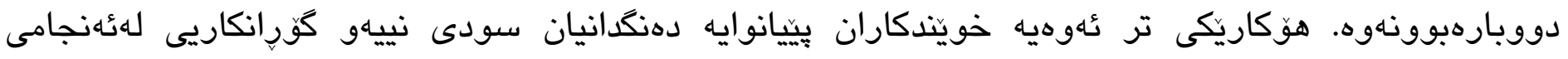

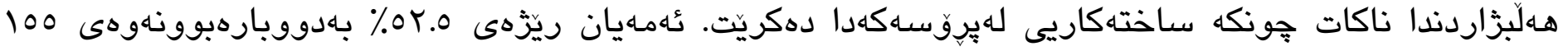

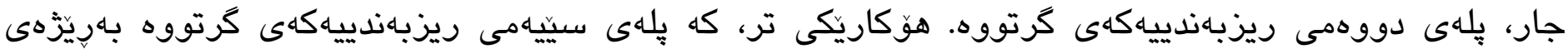

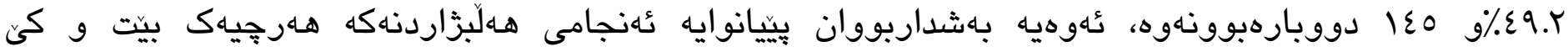

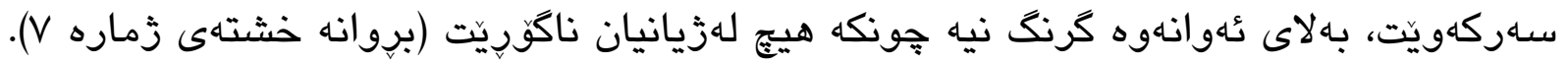

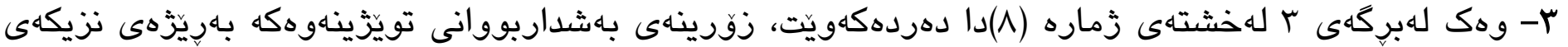

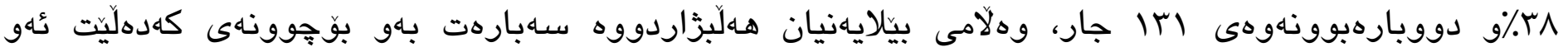
زانياريانهى لهسوّيال ميديا بهرجاوى بهشداربووان دهكهون، كاريكهريى لهسهر برياريان دروستدكههن بو دهنكدان

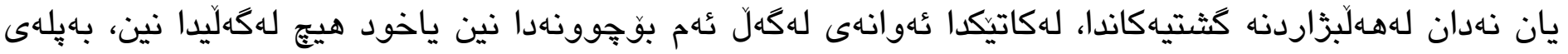
دووهم ديّت بهريزّهى نزيكهى 


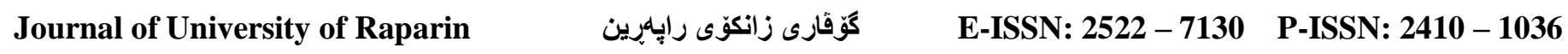

خشتهىی: كهميهين و زانيارييهكانى ههلبرّاردن لهسوشيال ميديا

\begin{tabular}{|c|c|c|c|c|c|c|c|c|c|c|c|}
\hline \multicolumn{2}{|c|}{ هيج للهكالَّدانيم } & \multicolumn{2}{|c|}{ للهكالَّبدانيم } & \multicolumn{2}{|c|}{ بيّلايهنم } & \multicolumn{2}{|c|}{ لـ لـكَلْيدام } & \multicolumn{2}{|c|}{ زوّر للكَّلَّدام } & & \\
\hline ريّزْه \% & دوباره & ريّزْه \% & دوباره & ريّزْه \% & دوباره & ريّزْه \% & دوباره & ريّزْه\% & دوباره & & \\
\hline$\% Y \cdot . T T$ & $V^{\prime}$ & $\% 1 \leq .0$ & 0. & 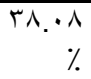 & 141 & $\% 11$ & $T Y$ & $\% \wedge . V Y$ & $r$. & 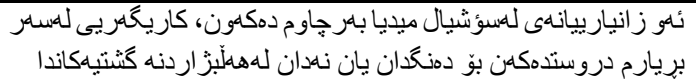 & $r$ \\
\hline$\%$ \%५. У & 94 & $\begin{array}{r}r \cdot r \varepsilon \\
\%\end{array}$ & V. & $\%$ \%. & $1 . \mathrm{V}$ & $\begin{array}{r}11.77 \\
\%\end{array}$ & $\varepsilon V$ & $\%$ \%. & rA & 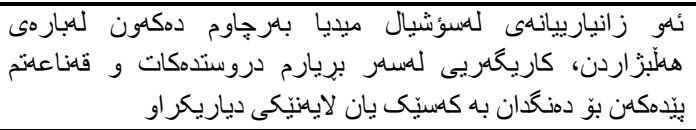 & $\varepsilon$ \\
\hline$\% \curlyvee \wedge . \leqslant \wedge$ & 91 & $\begin{array}{r}r \cdot 0 \\
\%\end{array}$ & 79 & $\begin{array}{r}1 . r 9 \\
\%\end{array}$ & $1 \cdot 1$ & $\begin{aligned} \% \\
1 T . T V\end{aligned}$ & $\varepsilon 7$ & $\% 7.71$ & rr & 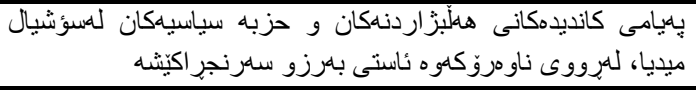 & 0 \\
\hline$\% 19 . \leqslant V$ & TV & $\begin{aligned} \text { IV.VT } \\
\%\end{aligned}$ & 71 & 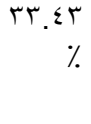 & 110 & $\begin{array}{r}r \text { r.T人 } \\
\%\end{array}$ & $V V$ & $\% 7.9 \mathrm{~V}$ & $T \leqslant$ & 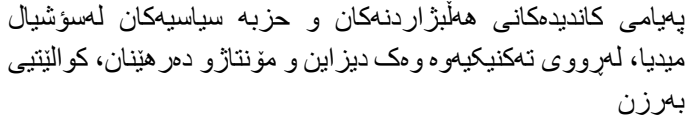 & 7 \\
\hline$\% 1 . \times 0$ & rv & $\begin{array}{r}11.5 \\
\%\end{array}$ & ri & $\begin{array}{r}r 7.10 \\
\%\end{array}$ & 9. & $\% r \vee . q$ & 97 & $\begin{array}{r}r \varepsilon .1 Y \\
\%\end{array}$ & NT & 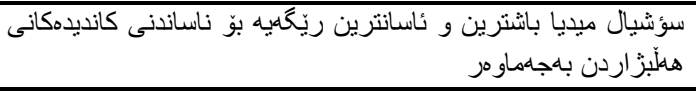 & V \\
\hline$\varepsilon \cdot .91$ & $1 \leqslant 1$ & $\begin{array}{r}11.90 \\
\%\end{array}$ & $\leqslant \wedge$ & $\begin{array}{r}r 9.17 \\
\%\end{array}$ & 1.1 & $\% 9.09$ & r & $\% 7.1$ & YI & 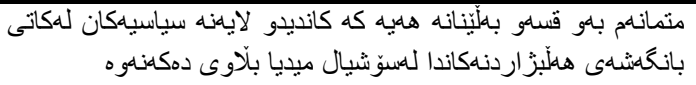 & $\wedge$ \\
\hline$\%$ \%ч.V & 94 & $\begin{array}{r}10.10 \\
\%\end{array}$ & 09 & $\begin{array}{r}\text { rY.00 } \\
\%\end{array}$ & 114 & $\begin{array}{r}10.91 \\
\%\end{array}$ & 00 & $\% \vee .00$ & $r_{7}$ & 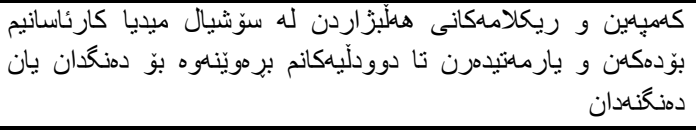 & 9 \\
\hline$\%$ \%.r & 111 & $\begin{array}{r}10.11 \\
\%\end{array}$ & or & $\begin{array}{r}r 9.70 \\
\%\end{array}$ & $1 \cdot r$ & \%r. & $\varepsilon r$ & $\% \wedge . \vee r$ & $r$. & 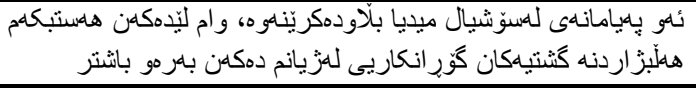 & 1. \\
\hline
\end{tabular}

ع- سهبارهت بهو بوّوونهش كه نئه زانيارييانهى لهسوشيال ميديا بهرجاوى بهشداربووان دهكهون لهبارهى

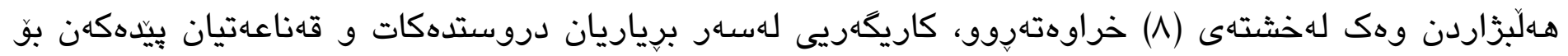

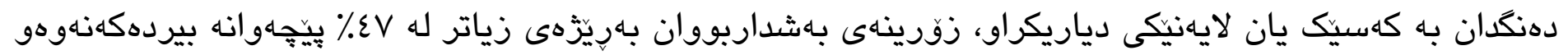

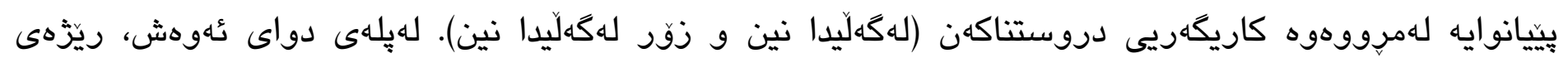

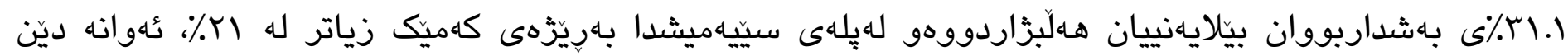

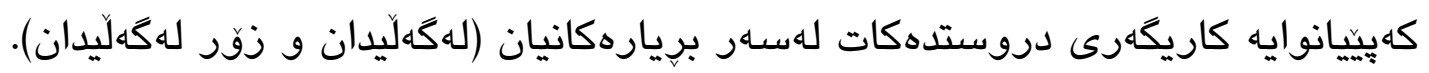

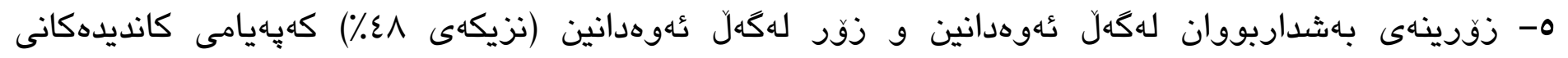

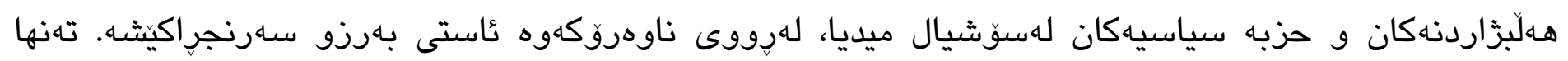

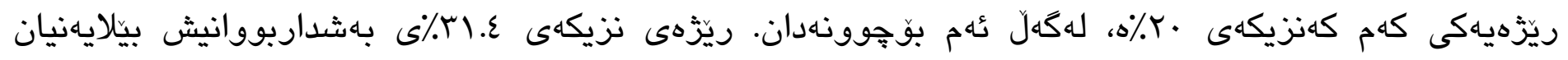

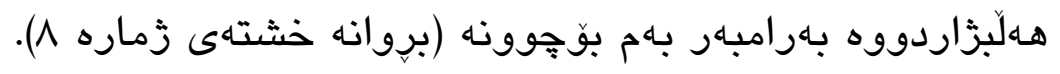

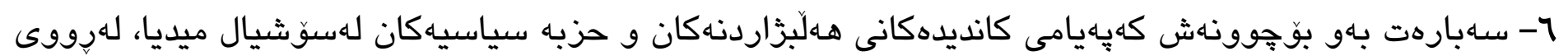

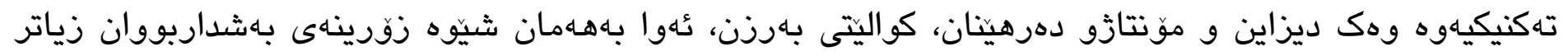

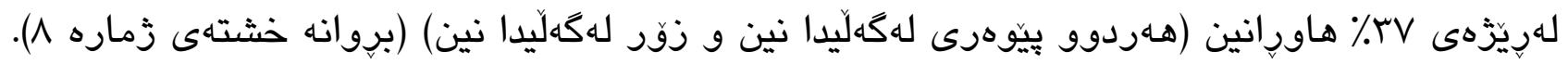




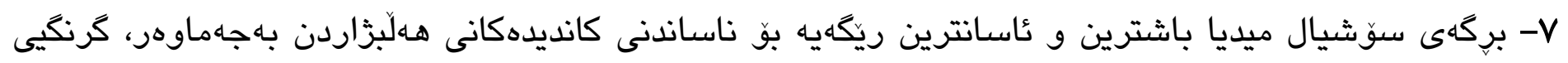

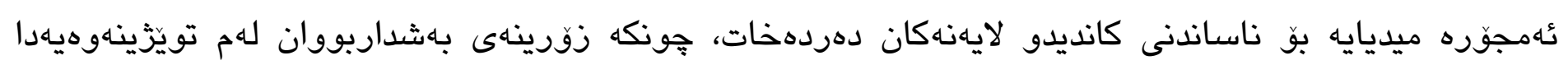

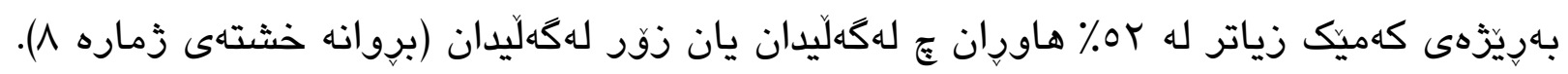

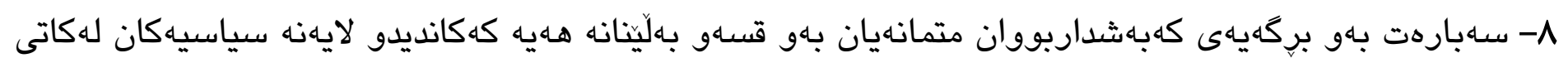

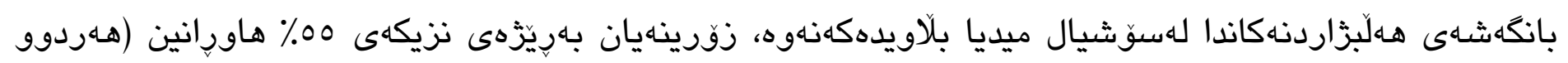

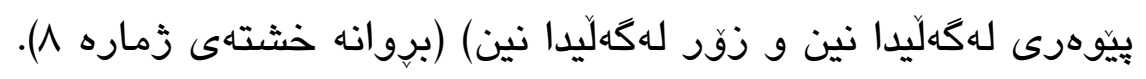

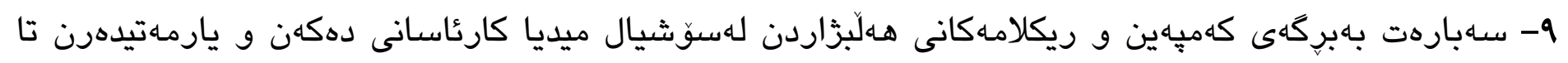

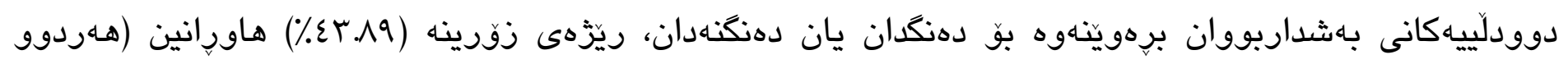

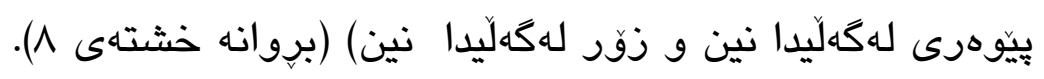

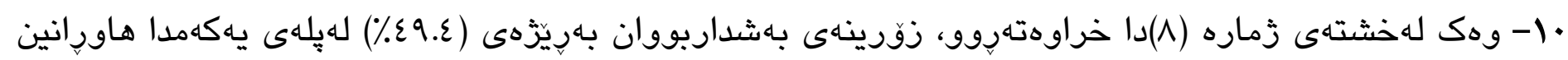

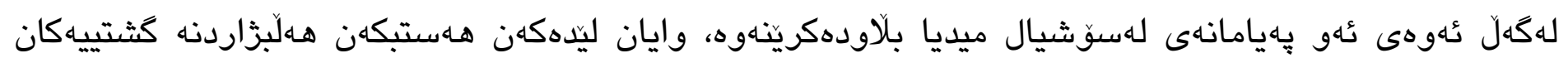

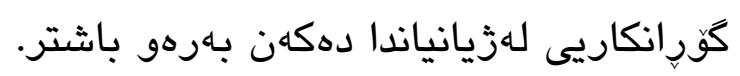

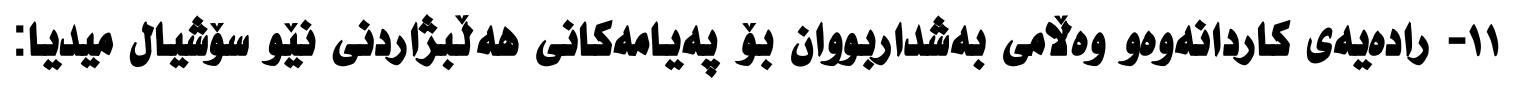

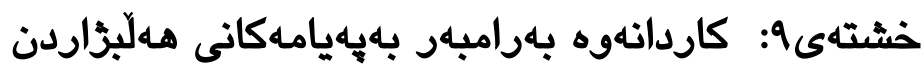

\begin{tabular}{|c|c|c|}
\hline ريّزّه & دووبارهبوونهوه & \\
\hline$\%$ & $r \leq$ & زوّر \\
\hline$\% r \cdot .1$ & 79 & كهم \\
\hline \%rr.r & $\wedge$. & زوّر كهم \\
\hline$\%$ ะ . V & IVI & هيج \\
\hline$\% 1 \ldots$ & $\Gamma \leqslant \varepsilon$ & كوّ \\
\hline
\end{tabular}

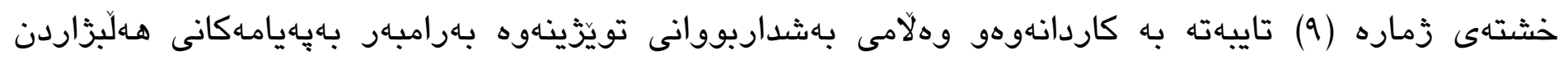

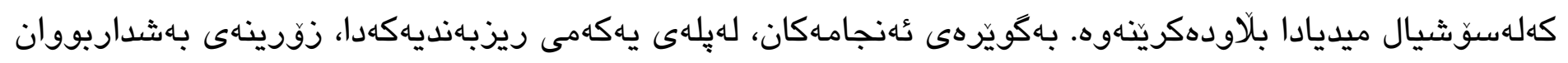

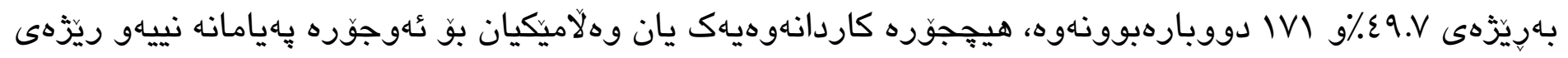

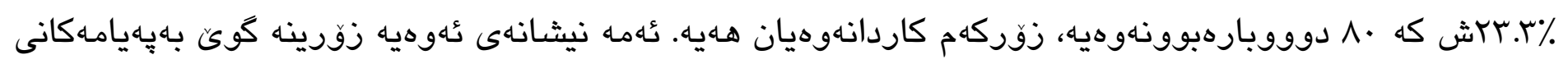

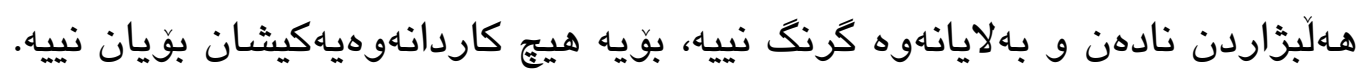




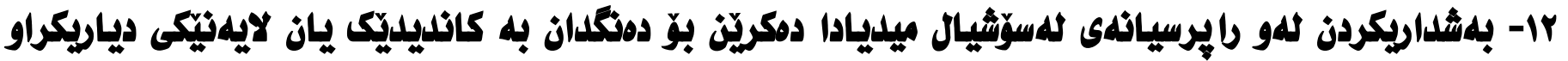

خشتهى • (: بهشداريكردن لهرايرسيهكانى سوشيال ميديا بو دهنكدان به كانديد يان لايهنيك

\begin{tabular}{|c|c|c|}
\hline رِيْزه & دووبار مبوونهاوه & \\
\hline$\% 11.7$ & $\varepsilon$. & 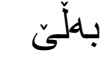 \\
\hline$\% \vee 9 . \vee$ & YVE & نهخجِّر \\
\hline$\% \wedge . \vee$ & $r$. & ن ازاز انم \\
\hline$\% 1 \ldots$ & $r \leqslant \varepsilon$ & كوّ \\
\hline
\end{tabular}

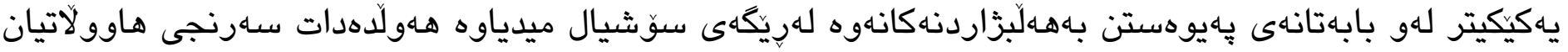
رابكيشيت عُهو رايرسيانهيه كهبو دهنكدان بهكانديديك يان لايهنيكى دياريكراو دروستدهرين. وهك لهخشتى زماره

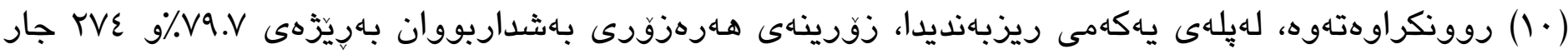
دووبارهبوونهوه، هيج بهشداريان لهوجوره رايرسيانه نهكرووهو دهنكيان بههيج لايهن يان كانديديكي نهداوه. ئهمها

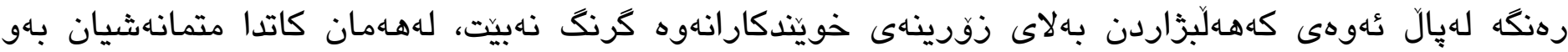
رايرسيانهو ئهنجامهانيشيان نييه.

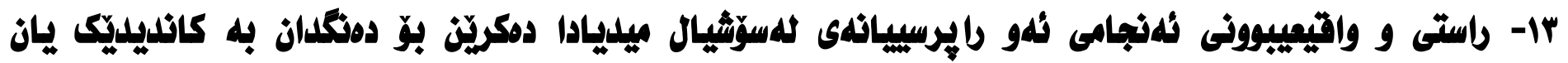
لايلئنى دياريكراو خشتهى ||: راستيى ئهنجامهانى ههلبُراردن و كونجانيان لكهل واقيع

\begin{tabular}{|c|c|c|}
\hline ريّزه & دووبارهبوونهوه & \\
\hline$\%$ \%. & r & بـاهلّى \\
\hline$\%$ \% .Y & YMI & ن نهيّز \\
\hline$\%$ \% & $9 \mathrm{~V}$ & نازانم \\
\hline$\% 1 \ldots$ & $r \varepsilon \varepsilon$ & كو \\
\hline
\end{tabular}

وهك لهخشتهى زماره (1)(1) روونكراوهتهوه، ريّزهيهكى زور كهم، تهنها 7. بهدووبارهبوونهوهى تهنها 7r كهس لهكوى عُع خوينّكاردا، بيّيانوايه ئهو رايرسيانهى لهسهر پِاتفورم و سايتهكانى سوّشيال ميديا ئهنجام دهدريّن تايبهت بهدهنكدان بهلايهن و كهيكيى دياريكراو راستن و رهنكدانهوهى واقيعن. زوقرينهى هـهره زوّىى بهشداربووان،

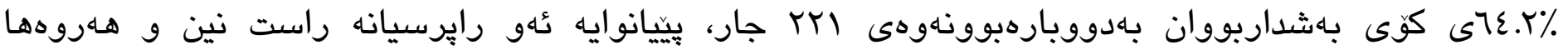

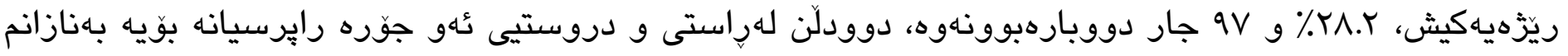


وهلاميان داوهتهوه. زانياريهكانى سهر سوّشيال ميديا لهلايهن بهكارهينّارانيهوه زوّر متمانهينيكراو نين و زوّرجار

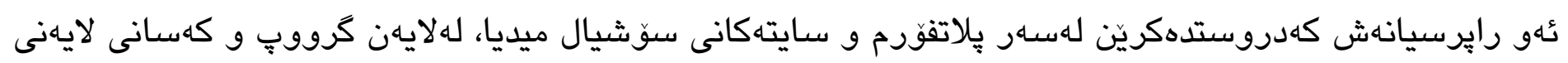

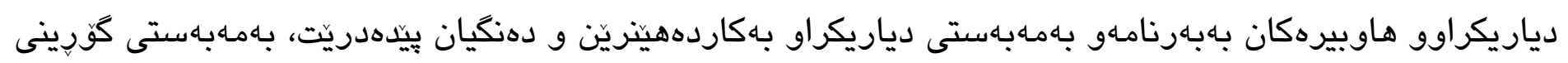

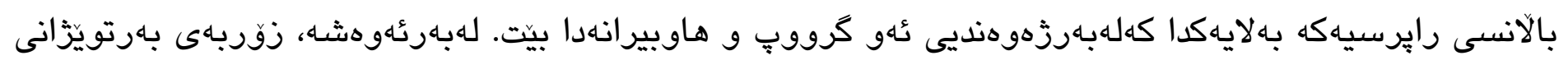

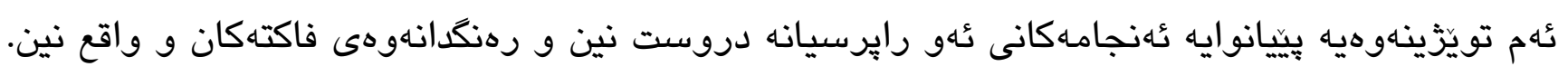

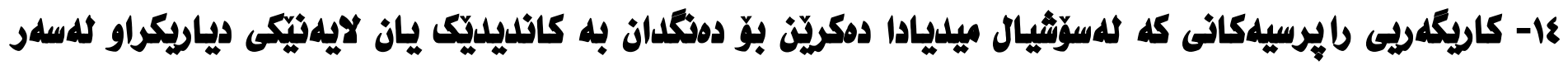
رهوتثارى دمذكلدان

خشتهى ا: كاريكهريى رايرسيهكانى سوّيال ميديا لهسهر ردفتارى ددنكدان

\begin{tabular}{|c|c|c|}
\hline ريّزَه & دووبارهبوونهوه & \\
\hline \% & $r q$ & زقود \\
\hline$\%$ \% & 1.1 & كهم \\
\hline$\%$ & $r \cdot \varepsilon$ & هيج \\
\hline$\% 1 \ldots$ & $r \varepsilon \varepsilon$ & كوق \\
\hline
\end{tabular}

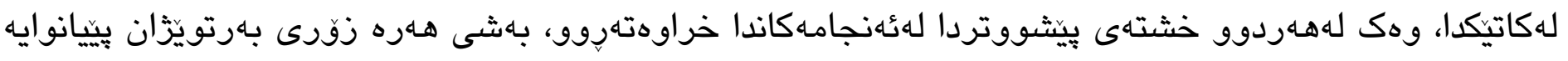

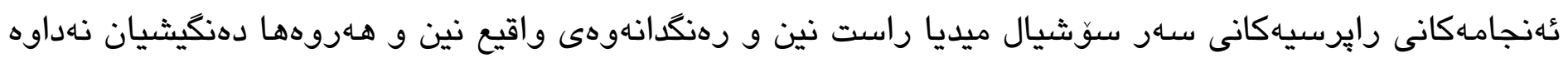

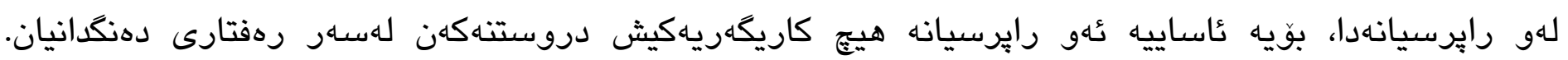

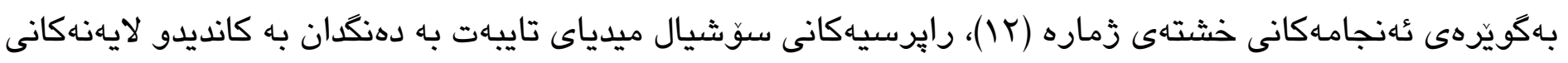

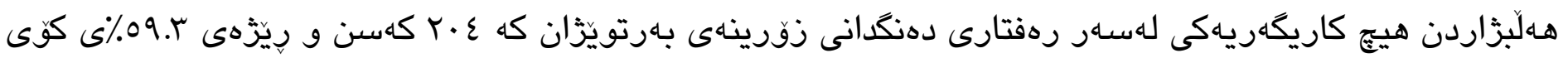

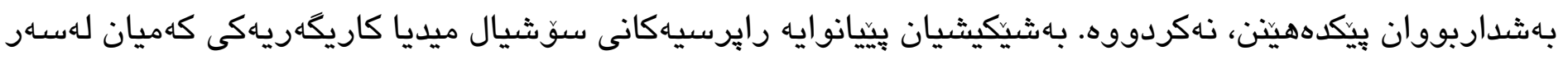

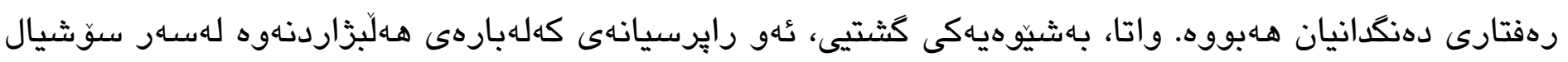

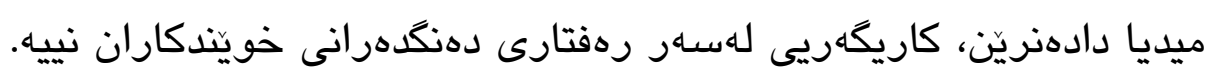




\section{ب-r شيكردندومى بلهيومثليى Correlation Analysis}

خشتهى إ: بهيوهنديى نيوان سوّشيال ميدياو رهفتارى دهنكدانى خوينّكارانى زانكوكان Correlations

\begin{tabular}{|c|c|c|c|c|}
\hline & & & SM_Average & EB_Average \\
\hline \multirow{8}{*}{ Spearman's rho } & \multirow{4}{*}{ SM_Average } & Correlation & 1.000 & $.737^{* *}$ \\
\hline & & Coefficient & & \\
\hline & & Sig. (2-tailed) & & . 000 \\
\hline & & $\mathrm{N}$ & 344 & 344 \\
\hline & \multirow{4}{*}{ EB_Average } & Correlation & $.737^{* *}$ & 1.000 \\
\hline & & Coefficient & & \\
\hline & & Sig. (2-tailed) & .000 & . \\
\hline & & $\mathrm{N}$ & 344 & 344 \\
\hline
\end{tabular}

$* *$. Correlation is significant at the 0.01 level (2-tailed).

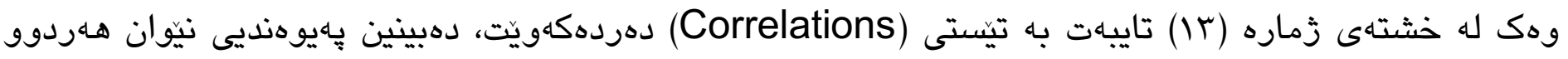

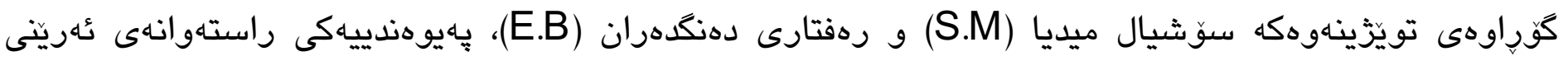

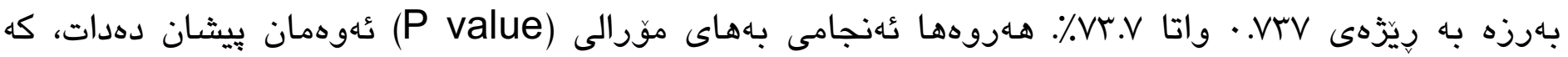

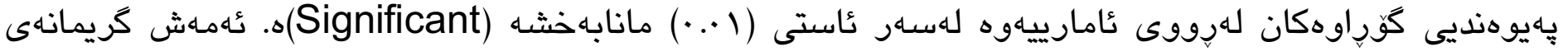

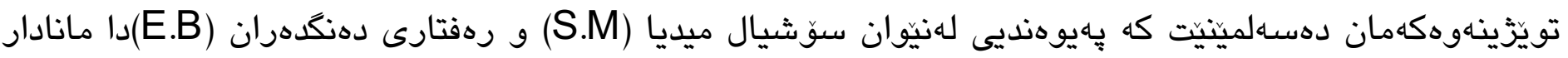

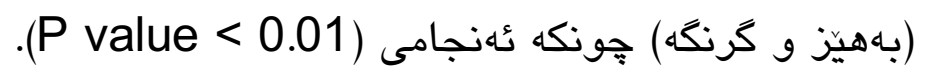

\section{دروئلهزجام:}

ديارترين ئهو دهرئهنجامانهى كه ئه تويّزينهوهيه لهبهر روّشنايى ئهنجامهاندا بيّيكهيشتووه، بريتين لهمانهى خوارهوه:

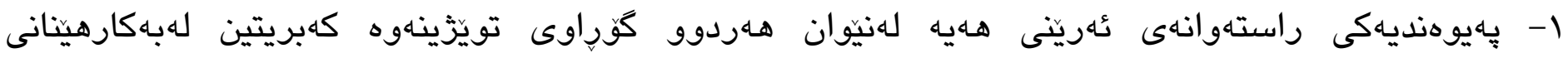

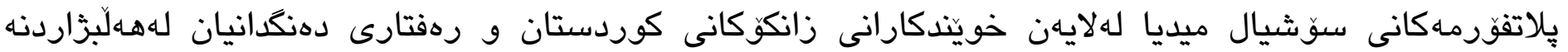
كَثتيهكاندا.

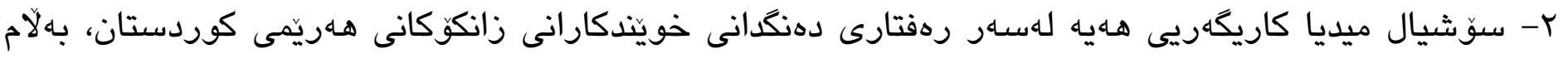

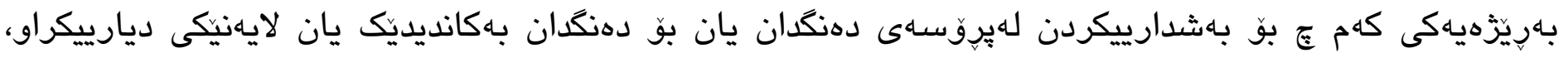




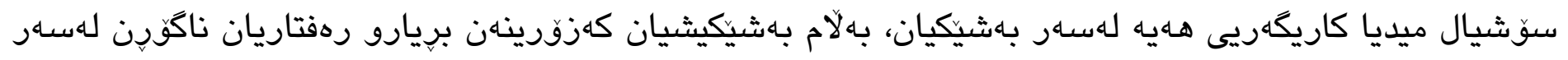

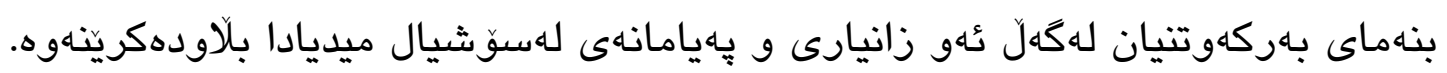

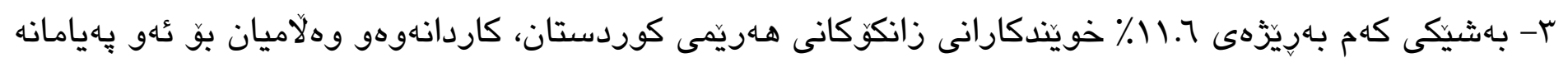

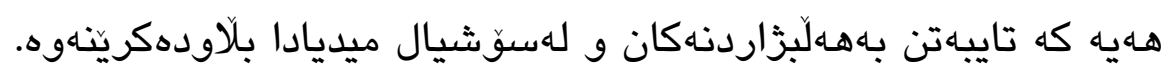

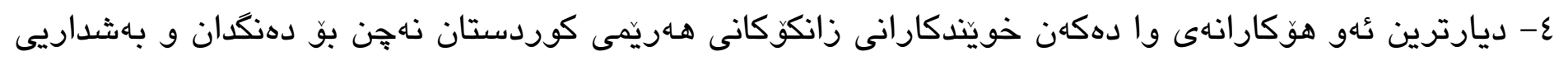

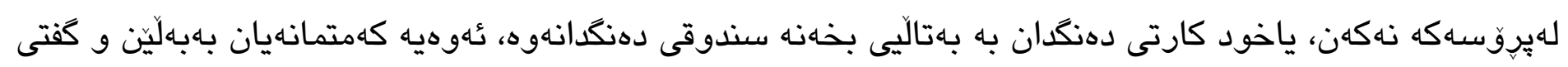

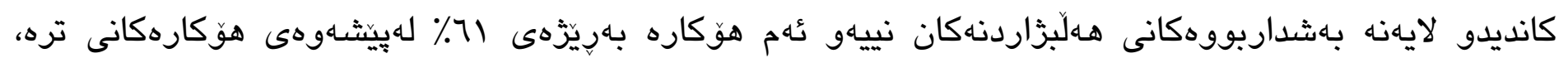

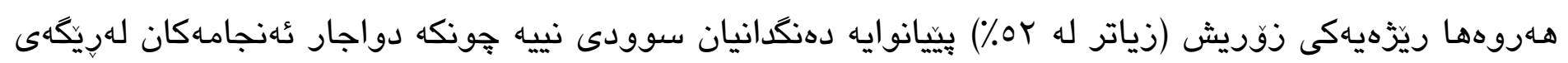

ساختهكارييهوه دياريدهكرين.

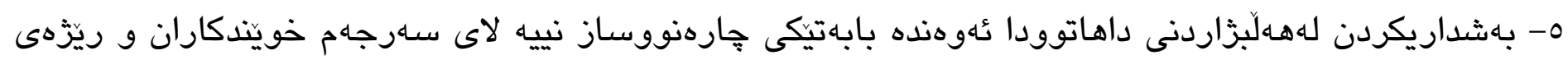

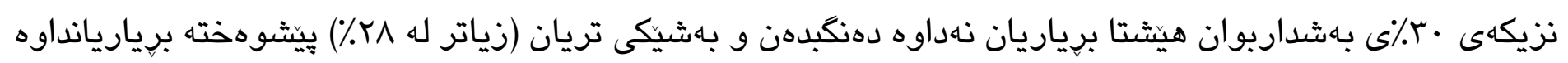
نهجن.

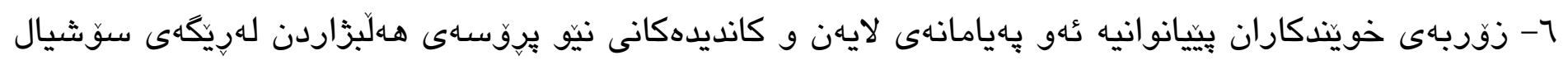

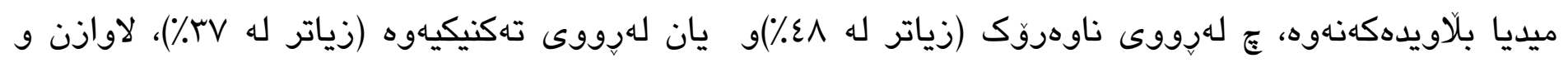
لهئاستيكى نزمدان.

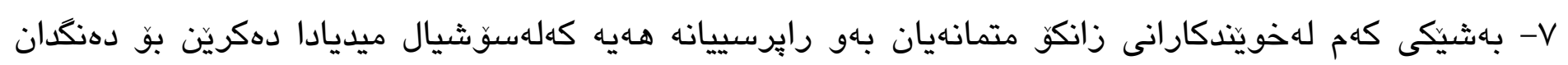

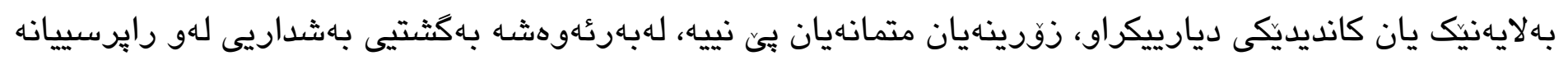

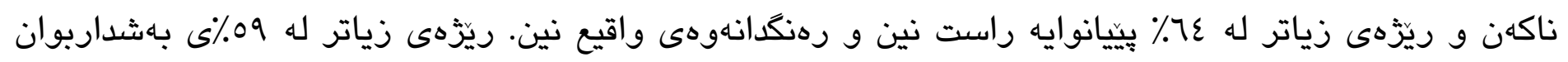

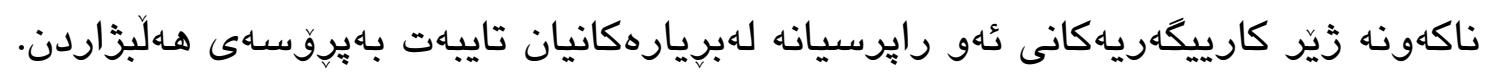




\section{The Effects of Social Media on the University Students' Voting Behavior in General Elections in the Kurdistan Region}

\section{Karwan Ali Qadir}

Public Relations and Marketing Department, College of Technical Administration, Sulaimani Polytechnic University, Sulaimani, Kurdistan Region, Iraq.

E-mail: karwan.ali@spu.edu.iq

\section{Abstract:}

The main goal of this research is to know and display the extent in which social media sites and platforms affect the voting behavior of the university students in the Kurdistan region during general elections, either to participate in the election or to vote for a specific candidate or political party. It also explores how the students participate and interact with the electoral messages and information that are published on social media platforms. This research is a political communication study, which relies on the survey method utilizing questionnaire form as a tool for data collection from the participants. The questionnaire form was designed and implemented online through Google Form and was sent to the participants through Email, Messenger, Viber and Whatsup, to the university student in different universities in the Kurdistan region. As such, 344 persons of the sample have filled up the questionnaire form in one week from 10 to 16 August 2021. The results of the study were displayed in tables and were analyzed through descriptive method, in addition to the use of SPSS statistics software to find correlation between the two main variables of the study.

One of the most prominent results of this study was that only a small proportion of the participants (almost 27\%) are influenced by social media to change their voting behavior such as deciding to vote or no, and voting for a specific candidate or political party. Another noticeable result was that the majority of the participants with almost (50\%) do not trust the promises and speeches of the candidates and political parties that are published on social media platforms.

Keywords: Social Media, Political Participation,Voting, General Elections, Kurdistan Region. 


\section{References:}

Ahmad, Araz, \& Hameed, Hakem. (2021) The Use of Social Media and its Effect on University Students' Academic Skills in Iraqi Kurdistan Region. Journal of University of Raparin, 8(2), 149-167. https://doi.org/10.26750/Vol(8).No(2).Paper_7

Ajibola, Akinade (2018) The influence of social media on the voting behavior of the youth in South East Nigeria, MA dissertation, University of Nigeria

Aslan, Avşar; Karakoç, Enderhan and Bekiroğlu, Onur (2021) The Effect of Social Media on Voter Behavior: The Sample of Kayseri Province, (Online), REVISTA ARGENTINA , (XXX)1, pp. 828-840, Available from: https://www.revistaclinicapsicologica.com/data-cms/articles/20210225011942pmSSCI-552.pdf,

[Accessed: 18 August 2021]

Baran, S. J. (2010) Introduction to Mass Communication: Media Literacy and Culture, (6th ed). New York: McGraw Hill

Bennett, W. L., \&Iyengar, S. (2008) A new era of minimal effects? The changing foundations of political communication, Journal of Communication, 58, 707-731.

Biswas, Aindrila; Ingle, Nikhil and Roy, Mousumi (2014) Influence of social media on voting behavior, Journal of Power, Politics \& Governance, pp. 127-155

Cogburn, Derrick. L. and Vasquez, Fatıma, K. Espinoza (2011) From Networked Nominee to Networked Nation: Examining the Impact of Web 2.0 and Social Media on Political Participation and Civic Engagement in the 2008 Obama Campaign. Journal of political marketing, (10) 1-2, pp.189-213, Available from: https://papers.ssrn.com/sol3/papers.cfm?abstract_id=2854273, [Accessed: 18 August 2021]

Deth, Jan W. Van (2016) What is political participation? (Online), Oxford Research Encyclopedias, Available from: $\quad$ https://oxfordre.com/politics/view/10.1093/acrefore/9780190228637.001.0001/acrefore9780190228637-e-68 , [Accessed: 20 August 2021]

Diamond, Larry \& Plattner, Marc F. (2012) Liberation technology: Social media and the struggle for democracy. Baltimore: The Johns Hopkins University Press

Distaso, Marcia and Mccorkindale (2017) The science of influence: How social media affects decision making in the healthcare, travel, retail, and financial industries, (Online), Institute of public relations, Available from: https://instituteforpr.org/wp-content/uploads/Science-of-Influence-Report-1-1.pdf, [Accessed: 17 August 2021] 
Douglas, Sara; Raine, Roxanne B.; Maruyama, Misa; Semaan, Bryan and Robertson, Scott P. (2015) Community matters: How young adults use Facebook to evaluate political candidates, Information Polity, vol. 20, no. 2-3, pp. 135-150.

Eulau, Heinz; Webb, Paul David and Gibbins, Roger (2020) Election, (Online), Encyclopedia Britannica, Available from: https://www.britannica.com/topic/election-political-science. [Accessed 21 August 2021]

Froehlich, Andrew (2020) What's the difference between social media and social networking? (Online), Available from: https://searchunifiedcommunications.techtarget.com/answer/Whats-the-difference-between-socialmedia-and-social-networking, [Accessed: 20 August 2021]

Fujiwara, Thomas; Muler, Karstan and Schwarz, Carlo (2021) The effect of social media on elections: Evidence from the United States, (Online), Available from: https://www.nber.org/papers/w28849, [Accessed: 12 August 2021]

Heblich, Stephan (2016) The effect of the internet on voting behavior, (Online), IZA World of Labor, Available from: https://www.econstor.eu/bitstream/10419/148519/1/iza-wol-294.pdf [Accessed: 13 August 2021]

Ibrahim, Jimoh Modibbo (2019) Influence of social media on voter's behavior in the 2015 presidential election in Ilorin-Metropolis, MA dissertation, Kwara State University

Ignant, Chanelle (2016) How does social media shape our political views? (Online), Available from: https://www.kqed.org/education/311498/how-does-social-media-shape-our-political-views, [Accessed: 10 August 2021]

JCR Publications Repository (2020) Technology and Democracy: Understanding the influence of online technologies on political behaviour and decision-making, (Online), Available from: https://publications.jrc.ec.europa.eu/repository/handle/JRC122023, [Accessed: 10 August 2021]

Kakashekh, Hardawan Mahmoud; Murad, Hersh Rasool; Ahmad, Araz Ramazan and Saud, Muhammad (2021) Effects of the Facebook Boycott Campaign on Turkish Products and its Influence on Demand of Kurdish Consumers 2020, UKH Journal of social sciences, 5(1), 98-106. https://doi.org/https://doi.org/10.25079/ukhjss.v5n1y2021.pp98-106

Kamiloglu, Fatma and Erdogan, Emre (2014) Effects of social media on civil and political participation and a field of survey over on Facebook, (Online), Online Journal of Communication and Media Technologies, 4 (3), Available from: https://www.ojcmt.net/download/effects-of-social-media-on-civil-and-politicalparticipation-and-a-field-of-survey-over-on-facebook.pdf, [Accessed: 1-4-2021]

Kasenally, Roukaya and Awatar, Dooshweena (2017) Social media, election and political engagement: the 2014 general election in Mauritius, Journal of African Elections, (16) 2, pp. 47-70. 
Kwak, N.,Williams, A.,Wang, X., \& Lee, H. (2005) Talking politics and engaging politics: An examination of the interactive relationships between structural features of political talk and discussion engagement. Communication Research, 32, 87-111.

Merkley, Lisi (2020) How social media impacts political views, (Online), Available from: https://universe.byu.edu/2020/08/06/social-media-use-impacts-political-views/, [Accessed: 9 August 2021]

Mutz, D. (2002). Cross-cutting social networks: Testing democratic theory in practice. American Political Science Review, 96(1), 111-126

Pew Research Center (2019) Teens' Social Media Habits and Experiences, (online), Available from: https://www.pewresearch.org/internet/2018/11/28/teens-and-their-experiences-on-social-media/,

[Accessed: 9 August 2021]

Schleffer, Guy and Miller, Benjamin (2021) The Political Effects of Social Media Platforms on Different Regime Types, (Online), Texas National Security review, Available from: https://tnsr.org/2021/07/the-politicaleffects-of-social-media-platforms-on-different-regime-types/, [Accessed: 4 August 2021]

Schmidt, Eric and Cohen, Jared (2010) The Digital Disruption: Connectivity and the Diffusion of Power, (online), Foreign Affairs, Available from: https://www.foreignaffairs.com/articles/2010-10-16/digital-disruption, [Accessed: 5 August 2021]

Segado-Boj, Francisco and Diaz-Campo, Jesus (2020) Social media and its intersections with free speech, freedom of information and privacy: an analysis, ICONO, (18) 1, pp. 231-255.

Singer, Peter W. and Brooking, Emerson T. (2018) Like war: the Weaponization of social media, New York: Houghton Mifflin Harcourt Publishing Company

Smith, Tanner (2020) Social media influences young people to vote, (online), Mill Valley News, Available from: https://www.mvnews.org/how-social-media-is-influencing-people-to-vote/, [Accessed: 4 August 2021]

Trippi, Joe (2012) How Technology Has Restored the Soul of Politics, (Online), Technology Review, Available from: https://www.technologyreview.com/2012/12/18/84609/how-technology-has-restored-the-soul-ofpolitics/, [Accessed: 18 August 2021]

Uhlaner, Carole Jean (2015) political participation, In: Wright, James D. (ed.) International Encyclopedia of the Social \& Behavioral Sciences, (2nd ed.), NC, USA: Elsvier, pp. 504-508

Zhuravskaya, Ekaterina; Petrova, Maria and Enikolopov, Ruben (2020) Political effects of the internet and social media, Annual Reviews, (12), pp. 415-438. Available from: https://www.annualreviews.org/doi/pdf/10.1146/annurev-economics-081919-050239, [Accessed: 17 August 2021] 
كاروان علي قادر، هيرش رسول مر اد و احمد حةمة غريب (·r ·r) استخدامات منصات التو اصل الاجتماعي من قبل مو اطنبي اقليم كوردستان

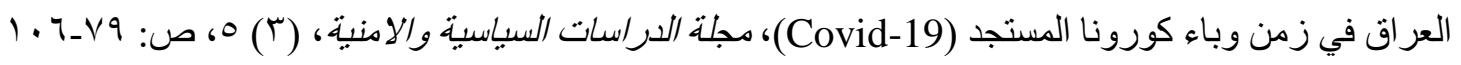

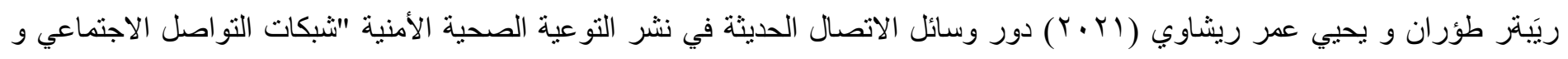
(Covid-19) holtps://portal.moi.gov.qa/securitystudies/post.html?eid=4\&cid=4\&pid=45 